\title{
A climate index for the Newfoundland and Labrador shelf
}

\author{
Frédéric Cyr ${ }^{1,2}$ and Peter S. Galbraith ${ }^{3}$ \\ ${ }^{1}$ Northwest Atlantic Fisheries Centre, Fisheries and Oceans Canada, St. John's, NL, Canada \\ ${ }^{2}$ Physics and Physical Oceanography, Memorial University of Newfoundland, St. John's, NL, Canada \\ ${ }^{3}$ Maurice Lamontagne Institute, Fisheries and Oceans Canada, Mont-Joli, QC, Canada
}

Correspondence: Frédéric Cyr (frederic.cyr@dfo-mpo.gc.ca)

Received: 17 November 2020 - Discussion started: 2 December 2020

Revised: 16 March 2021 - Accepted: 22 March 2021 - Published: 3 May 2021

\begin{abstract}
This study presents in detail a new climate index for the Newfoundland and Labrador (NL) shelf. The NL climate index (NLCI) aims to describe the environmental conditions on the NL shelf and in the Northwest Atlantic as a whole. It consists of the average of 10 normalized anomalies, or subindices, derived annually: winter North Atlantic Oscillation, air temperature, sea ice season severity, iceberg count, seasonal sea surface temperature, vertically averaged temperature and salinity at the Atlantic Zone Monitoring Program (AZMP) Station 27, summer cold intermediate layer (CIL) core temperature at AZMP Station 27, summer CIL area on three AZMP hydrographic sections, and bottom temperature on the NL shelf. This index runs from 1951 to 2020 and will be updated annually. It provides continuity in the production of advice for fisheries management and ecosystem status on the NL shelf, for which a similar but recently abandoned index was used. The new climate index and its subindices are available at https://doi.org/10.20383/101.0301 (Cyr and Galbraith, 2020).
\end{abstract}

\section{Introduction}

Climate indices are often regarded as simple ways to relate the mean environmental conditions to the state of an ecosystem. As changes in the ocean climate affect species distribution and the resilience of the world's ecosystems (IPCC, 2019), these climate indicators are currently in high demand. Useful and accessible climate indices are also keystone pieces of information for fisheries management, especially now that many governments and inter-governmental agencies show an increasing desire to implement an ecosystem approach to their fisheries management (e.g. for the North Atlantic; Levin et al., 2008; Pepin et al., 2019; KoenAlonso et al., 2019; Muffley et al., 2021).

In eastern Canada, climate indices are often used by Fisheries and Oceans Canada (DFO) in ecosystem studies and/or to inform fisheries scientists and managers as part of various regional assessments of marine resources. At DFO, these indices and related advice are often provided by scientists affiliated with the Atlantic Zone Monitoring Program (AZMP, Therriault et al., 1998). Created in 1998 following a general consensus that "changes in climate cannot be ignored as an explanation for fluctuations in marine resources" (from the Introduction of the founding document), the AZMP had a mandate to develop and implement an efficient and effective environmental monitoring program for the northwest Atlantic zone and then to maintain it through the years. The creation of the AZMP came as a direct consequence of the collapse of the Atlantic zone groundfish fisheries in the early 1990s, a period characterized by anomalously cold and potentially unfavourable environmental conditions for the stock, although the latter was highly debated (Lear and Parsons, 1993; de Young and Rose, 1993; Hutchings and Myers, 1994; Mullowney et al., 2019).

Since 2000, annual reports produced by AZMP scientists on the oceanographic and meteorological conditions of the Canadian Atlantic zone have been published through the Canadian Science Advisory Secretariat (CSAS; https://www. dfo-mpo.gc.ca/csas-sccs, last access: 15 March 2021). The idea of combining several normalized anomalies into a single index representative of the climate of a large area was first developed by Petrie et al. (2006a) for the meteorological, sea ice and sea surface temperature (SST) parameters in eastern Canada and by Petrie et al. (2006b) for the physi- 
Table 1. Review of AZMP reports that made use of composite or climate indices. The Table is separated into three sections: (1) meteorological, sea ice and SST conditions off eastern Canada; (2) physical oceanographic conditions (review year 2005-2008) and meteorological and sea ice conditions (after 2009) on the Scotian shelf and Gulf of Maine; and (3) physical oceanographic conditions (including sea ice and atmosphere) on the Newfoundland and Labrador shelf. Note that the entries between Hebert et al. (2011) and Hebert et al. (2020) have not been included because their ocean composite index did not change. The different columns are, respectively, the year in review, the number of components in the composite index, the time series used and the name given to this index in the document.

\begin{tabular}{|c|c|c|c|c|}
\hline & Year & No. comp. & Types of components* & Name \\
\hline \multicolumn{5}{|c|}{ Eastern Canada (ocean and atmosphere index) } \\
\hline Petrie et al. (2006a) & 2005 & 23 & NAO, airT, ice, SST & $\mathrm{n} / \mathrm{a}$ \\
\hline Petrie et al. (2007a) & 2006 & 23 & NAO, airT, ice, SST & Composite index \\
\hline Petrie et al. (2008a) & 2007 & 23 & NAO, airT, ice, SST & Composite index \\
\hline Petrie et al. (2009a) & 2008 & 23 & NAO, airT, ice, SST & Composite index \\
\hline \multicolumn{5}{|c|}{ Scotian shelf and Gulf of Maine (ocean only index) } \\
\hline Petrie et al. (2006b) & 2005 & 18 & botT, station $\mathrm{T}$ & $\mathrm{n} / \mathrm{a}$ \\
\hline Petrie et al. (2007b) & 2006 & 18 & botT, station $\mathrm{T}$ & Composite index \\
\hline Petrie et al. (2008b) & 2007 & 18 & botT, station T & Composite index \\
\hline Petrie et al. (2009b) & 2008 & 18 & botT, station T & Composite index \\
\hline Hebert et al. (2011) & 2009-2010 & 18 & botT, station T & Composite index \\
\hline .. & $\ldots$ & $\cdots$ & $\ldots$ & $\ldots$ \\
\hline Hebert et al. (2020) & 2018 & 18 & botT, station $\mathrm{T}$ & Composite index \\
\hline \multicolumn{5}{|c|}{ Newfoundland and Labrador shelf (ocean and atmosphere index) } \\
\hline Colbourne et al. (2006) & 2005 & 0 & $\mathrm{n} / \mathrm{a}$ & $\mathrm{n} / \mathrm{a}$ \\
\hline Colbourne et al. (2007) & 2006 & 0 & $\mathrm{n} / \mathrm{a}$ & $\mathrm{n} / \mathrm{a}$ \\
\hline Colbourne et al. (2008) & 2007 & 26 & NAO, airT, ice, icebergs, SST, S27, botT, CIL, secT & Composite index \\
\hline Colbourne et al. (2009) & 2008 & 26 & NAO, airT, ice, icebergs, SST, S27, botT, CIL, secT & Composite climate index \\
\hline Colbourne et al. (2011) & 2010 & 26 & NAO, airT, ice, icebergs, SST, S27, botT, CIL, secT & Composite climate index \\
\hline Colbourne et al. (2012) & 2011 & 26 & NAO, airT, ice, icebergs, SST, S27, botT, CIL, secT & Composite climate index \\
\hline Colbourne et al. (2013) & 2012 & 26 & NAO, airT, ice, icebergs, SST, S27, botT, CIL, secT & Composite climate index \\
\hline Colbourne et al. (2014) & 2013 & 26 & NAO, airT, ice, icebergs, SST, S27, botT, CIL, secT & Composite climate index \\
\hline Colbourne et al. (2015) & 2014 & 28 & NAO, airT, ice, icebergs, SST, S27, botT, CIL, secT & Composite climate index \\
\hline Colbourne et al. (2016) & 2015 & 28 & NAO, airT, ice, icebergs, SST, S27, botT, CIL, secT & Composite climate index \\
\hline Colbourne et al. (2017) & 2016 & 28 & NAO, airT, ice, icebergs, SST, S27, botT, CIL, secT & Composite climate index \\
\hline Cyr et al. (2019) & 2017 & 28 & NAO, airT, ice, icebergs, SST, S27, botT, CIL, secT & Composite climate index \\
\hline Cyr et al. (2020) & 2018 & 10 & NAO, airT, ice, icebergs, SST, S27, botT, CIL & NL climate index \\
\hline
\end{tabular}

n/a: not applicable. *NAO: winter NAO; airT: air temperature at different sites; ice: sea ice parameters; SST: sea surface temperature in different sub-areas; botT: bottom temperature in different sub-areas; stationT: temperature at monitoring stations (different depth ranges); S27: Station 27 temperature and salinity (different depth ranges); CIL: cold intermediate layer parameters; secT: mean temperature along repeated hydrographic sections.

cal oceanography of the Scotian shelf and the Gulf of Maine. These composite indices were derived by summing 23 and 18 individual normalized anomalies, respectively (see Table 1 for a review of CSAS publications using such indices). While the physical oceanographic index from the Scotian shelf and the Gulf of Maine is still produced annually (see Hebert et al., 2020, for latest update), the eastern Canada meteorological, sea ice and SST index was last produced by Petrie et al. (2009a). Starting with the annual report for 2009 conditions, the meteorological, sea ice and physical oceanographic conditions were integrated into a single report (Hebert et al., 2011, see also Table 1), and the eastern Canada atmospheric and ocean index was abandoned. Note that for the Newfoundland and Labrador (NL) shelf, sea ice and atmospheric conditions were reported together with the physical oceanographic conditions starting with the annual report of Colbourne et al. (2006), although no composite climate index was presented (see Table 1).

Following the approach of Petrie et al. (2006a, b), a composite climate index was developed for the NL shelf by Colbourne et al. (2008). This composite climate index was derived by summing 26 individual normalized anomalies (e.g. winter North Atlantic Oscillation, air temperature at several sites, surface and bottom temperature at several sites, average temperature, salinity and area of water colder than $0{ }^{\circ} \mathrm{C}$ along oceanographic transects, etc.; see Table 1). These individual components did not, however, begin with the same year. The number of components of this composite climate index was increased to 28 in 2015 (Colbourne et al., 2015). Although never explicitly named this way, this composite 
climate index (both the 26 and the 28 component definitions) rapidly gained popularity among biologists, ecologist and fisheries scientists in NL under the appellation Composite Environmental Index, or CEI, the term used hereafter. The CEI was used, for example, to assess the prospect of several commercial marine resources (Koen-Alonso et al., 2010; DFO, 2014), marine mammal stock fluctuations (DFO, 2020b; Hammill et al., 2021; Stenson et al., 2020) and the ecosystem productivity as a whole (NAFO, 2017, 2018). The CEI was last produced by Cyr et al. (2019).

A new climate index for the NL shelf is introduced here to ensure the continuity of the studies mentioned above and in a hope to feed new similar initiatives. This index was first introduced by Cyr et al. (2020), but it is formalized, detailed and made openly accessible for the first time here. At the moment, this index runs from 1951 to 2020 but will be updated annually (see Data availability). The main differences with previous versions are the reduced number of components (10) and the fact that the index is now calculated as the average of the different components rather than their sum. Details are provided in the next section.

\section{NL climate index components}

The NL climate index (NLCI) aims to represent the largescale climate conditions and state of the physical environment on the NL shelf and the Northwest Atlantic in general (see Fig. 1 for map). The index is a composite of 10 components (or subindices) estimated annually by DFO (e.g. Cyr et al., 2020). These subindices are presented in the following sub-sections.

The NLCI and most subindices start in 1951. Prior to 1951, there are too few observations for many of the subindices to achieve a level of accuracy and precision that would provide high confidence in their estimates. Except for the North Atlantic Oscillation (NAO), these subindices are presented in terms of normalized anomalies $(\tilde{X})$ :

$\tilde{X}=\frac{X-\bar{X}_{\text {clim }}}{\operatorname{SD}(X)_{\text {clim }}}$

where $X$ represents any annual time series, and $\bar{X}_{\text {clim }}$ and $\mathrm{SD}(X)_{\text {clim }}$ are the average and standard deviation of $X$ over the climatological period. Following recommendations from World Meteorological Organization standards, the climatological period used is 1991-2020 (World Meteorological Organization, 2017). Because this period was updated at the end of 2020, a complete series of relevant figures for this study are also provided in the Appendix referencing the previous climatological period of 1981-2010.

\subsection{North Atlantic Oscillation}

The North Atlantic Oscillation (NAO) refers to the anomaly in the sea-level-pressure (SLP) difference between the subtropical high (near the Azores) and the subpolar low (near

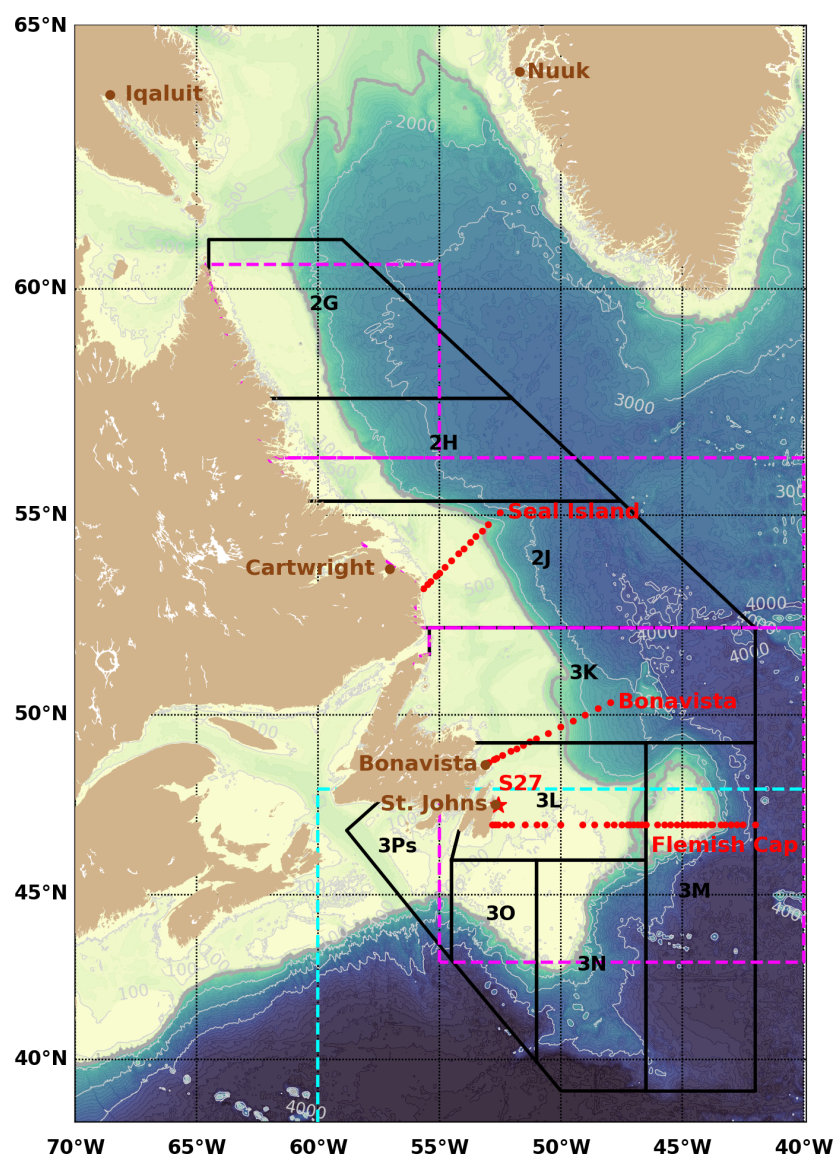

Figure 1. Map and main bathymetric features of the Northwest Atlantic ocean. NAFO Divisions (sub-areas 2 and 3) on the Newfoundland and Labrador (NL) shelf are drawn. The AZMP hydrographic sections Seal Island, Bonavista Bay and Flemish Cap are shown with red dots. Long-term AZMP hydrographic Station 27 is highlighted with a red star. The five stations used for the air temperature time series are shown in brown. The three regions used for sea ice calculations are drawn with dashed magenta lines: northern Labrador shelf, southern Labrador shelf and Newfoundland shelf, respectively, from north to south. The region used by the IIP for iceberg sightings south of $48^{\circ} \mathrm{N}$ is drawn in dashed cyan. The shelf break is delimited by a thicker and darker contour corresponding to the isobath $1000 \mathrm{~m}$ (used to clip the SST and bottom temperature).

Iceland). While several operational definitions of the NAO exist, the monthly NAO based on empirical orthogonal functions (EOF) from the National Center for Environmental Information of the National Oceanic and Atmospheric Administration is used here. This definition better represents the larger-scale influence of the SLP patterns above the Northwest Atlantic and tends to be less noisy than the station-based definition. This time series is available online (https://www.ncdc.noaa.gov/teleconnections/nao/, last access: 4 March 2021). Because the monthly NAO index is normalized over the 1950-2000 period, this subindex is not re-normalized here. 


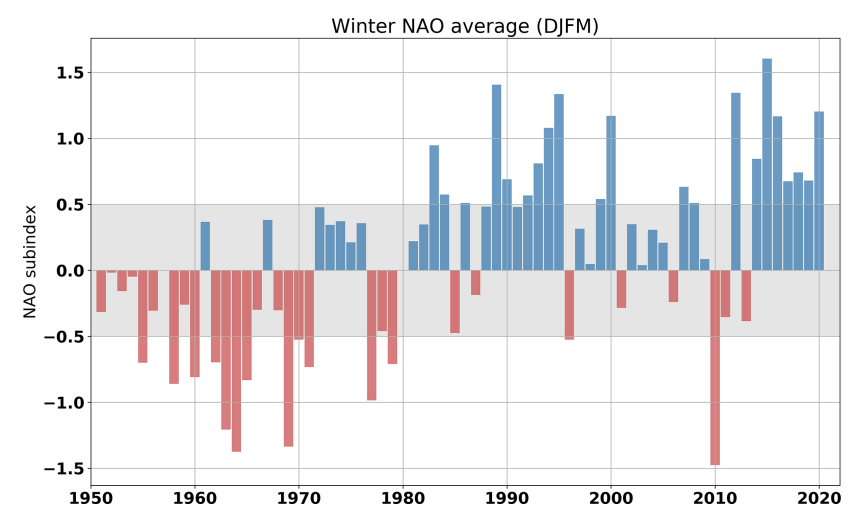

Figure 2. Winter North Atlantic Oscillation (NAO) index averaged over December to March. Here positive anomalies, generally indicative of colder conditions, are coloured in blue. The shaded area corresponds to $\pm 0.5 \mathrm{SD}$, indicating normal conditions. This time series is one component of the NL climate index.

The winter NAO, defined as the average of monthly values from December to March, is considered here (Fig. 2). A positive phase of the NAO index is usually associated with an intensification of the Icelandic Low and the Azores High SLPs. Except for some years for which the SLP patterns are spatially shifted (e.g. 1999, 2000 and 2018), positive winter NAO years usually favour strong northwesterly winds, cold air and sea surface temperatures, and heavy ice conditions in the Northwest Atlantic (Colbourne et al., 1994; Drinkwater, 1996; Petrie et al., 2007a). A predominance of a strongly positive winter NAO phase has persisted since 2012, including the record high of +1.61 in 2015 (the record low of -1.47 was in 2010). This recent positive phase of the NAO also corresponded to an intensification of the convection in the Labrador Sea (Yashayaev and Loder, 2017).

\subsection{Air temperature}

The air temperature subindex consists of the average of the annual normalized anomalies at five coastal communities around the Northwest Atlantic: Nuuk (Greenland), Iqaluit (Baffin Island), Cartwright (Labrador), and Bonavista and St. John's in Newfoundland (see Fig. 1). These sites were chosen because they are representative of both local (e.g. sea ice formation and SST) and remote (e.g. icebergs originating from Greenland and freshwater fluxes from the Canadian Arctic) effects on the NL shelf. While the data for Nuuk are obtained from the Danish Meteorological Institute (Vinther et al., 2006), the air temperature data from the Canadian sites are from the second generation of Adjusted and Homogenized Canadian Climate Data (AHCCD) that accounts for shifts in station location and changes in observation methods (Vincent et al., 2012). When necessary, they are updated using Environment Canada's National Climate Data and Information Archive.
Annual normalized anomalies since 1951 for these five sites are presented in Fig. 3 under the form of a stacked bar plot. Despite the fact that these sites are spread around the North Atlantic, they often exhibit consistency in the sign of their anomalies, especially in the periods of very cold or warm years. While 1972 appears as the coldest year of this time series, the period of the early 1990s exhibits a sustained period of cold air temperature, with 1991, 1992 and 1993 being respectively the sixth, second and third coldest years of the entire time series. This cold period was followed by the predominance of warmer-than-normal air temperatures at all sites from the mid-1990s to about 2013, with 2010 being the warmest year on record by a large extent. Except for 2015, which was the coldest year since 1993, and 2018 (slightly cold), recent years were close to normal.

\subsection{Sea ice}

Sea ice season duration and maximum cover area are estimated from ice cover products obtained from the Canadian Ice Service (CIS). The methodology is described in Galbraith et al. (2020) and briefly summarized here. The source CIS products consist of weekly geographic information system (GIS) charts covering the east coast for the period 1969-2020 and Hudson Bay for the period 1980-2020. The Hudson Bay charts include coverage of the northern Labrador shelf, and the east coast charts cover the southern Labrador shelf, as well as the Newfoundland shelf (Fig. 1). For each of the three regions, the seasonal maximum area of sea ice was determined, as well as the ice season duration (Fig. 4). The former accounts for partial coverage (as opposed to sea ice extent), and the latter is obtained from a spatial average of the number of weeks with sea ice at every pixel, with zeros counted for areas where no ice was present but the 30 year climatology shows some. The normalized anomalies of these six time series (duration and area over three regions) are averaged into a single index presented in a stacked bar plot (Fig. 4d). Each stacked colour in this plot represents its respective contribution to the average. The numerical values of this sea ice subindex are reported in a colour-coded scorecard at the bottom of this panel. Negative anomalies, indicative of warmer conditions, have been coloured red and positive anomalies blue. This time series corresponds to the sea ice contribution to the NL climate index. The periods of maximum sea ice cover and season duration are found in the early 1970s, mid1980 s and early 1990s. Since the early 1990s the severity of the sea ice season has gradually decreased, reaching the lowest values in 2011 and 2010. With the exception of a rebound to near-normal values in 2014-2016, sea ice conditions have been weak over recent years.

\subsection{Iceberg count}

The number of icebergs drifting south of $48^{\circ} \mathrm{N}$ in the Northwest Atlantic (see dashed cyan box in Fig. 1) has been mon- 


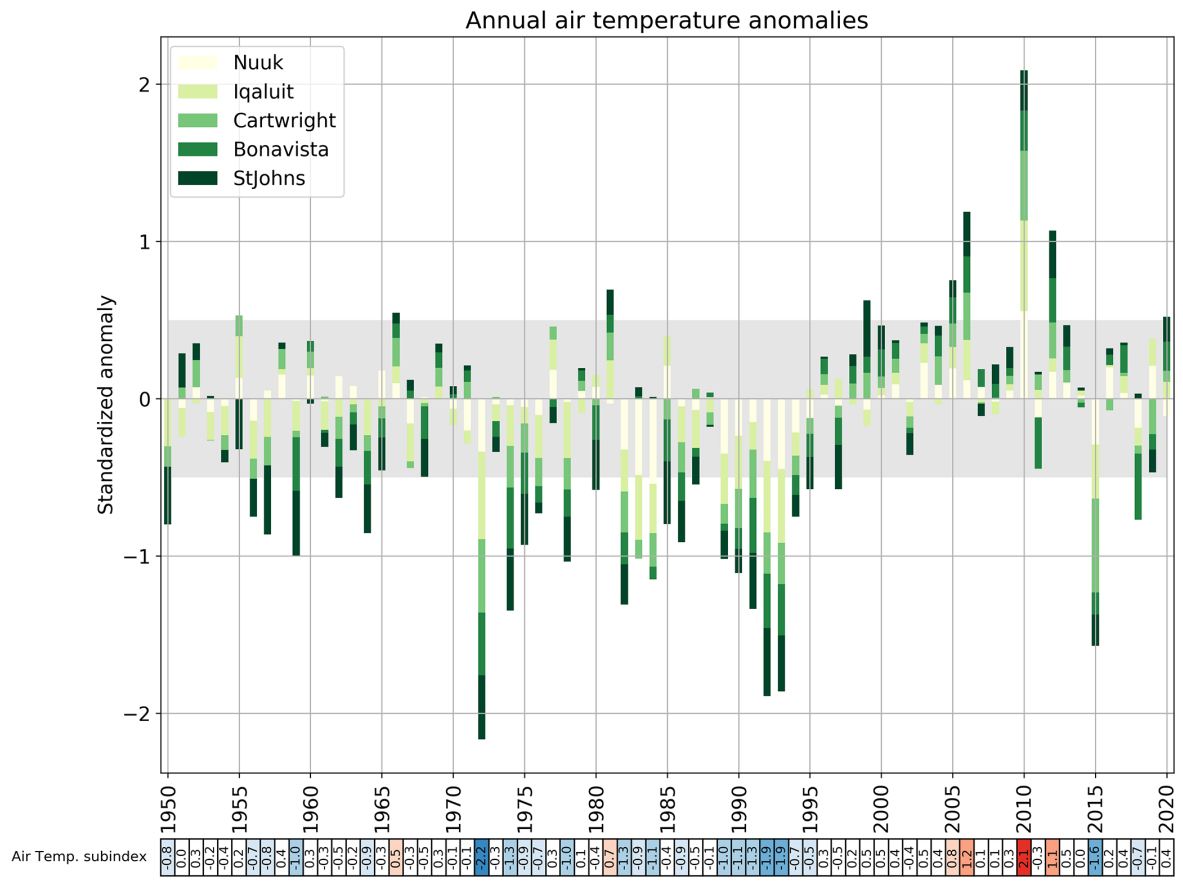

Figure 3. Normalized annual air temperature anomalies for Nuuk, Iqaluit, Cartwright, Bonavista and St. John's. This figure shows the average of the five stations, in which the length of each bar corresponds to the relative contribution of the individual station to the average. The shaded area corresponds to the 1991-2020 average \pm 0.5 SD. The numerical values of this time series are reported in a colour-coded scorecard at the bottom of the figure. Positive anomalies $(>0.5 \mathrm{SD})$ are coloured red, while negative anomalies $(<-0.5 \mathrm{SD})$ are coloured blue. In both cases, the darker the colour, the stronger the anomaly. White corresponds to the climatological average $\pm 0.5 \mathrm{SD}$. This time series is one component of the NL climate index.

itored by the International Ice Patrol (IIP) of the US Coast Guard since 1900 (International Ice Patrol, 2020). These icebergs mostly originate from western Greenland (Marson et al., 2018) and may carry with them important amounts of freshwater (Martin and Adcroft, 2010). The entire time series is presented in Fig. 5. The 121-year average annual number is 495, and the 1991-2020 average is 771. An iceberg count above 1500 has been observed in some years, including in 2014, 2019, and between the early 1980s and mid-1990s. The all-time record of 2202 was reached in 1984. Only 2 years (1966 and 2006) in the 121-year time series reported no icebergs south of $48^{\circ} \mathrm{N}$. Years with low iceberg numbers on the Grand Banks generally correspond to higher than normal air temperatures, lighter than normal sea ice conditions and warmer than normal ocean temperatures on the NL shelf. The normalized anomalies of this time series are provided in the form of a scorecard below the main panel of Fig. 5. This time series, starting from 1951, corresponds to the icebergs contribution to the NLCI.

\subsection{Sea surface temperature}

Sea surface temperatures (SSTs) used here are a blend of data from Pathfinder version 5.3 (1982-2020), the Maurice Lamontagne Institute (1985-2013) and the Bedford Insti- tute of Oceanography (1997-2020). Monthly anomalies are computed as the average of available daily anomalies at the pixel level within each geographical region, chosen to be the Northwest Atlantic Fisheries Organization (NAFO) Divisions of Fig. 1, except that here they are cropped at the shelf break. Details of the processing are in Galbraith et al. (2021) with the extended spatial coverage as in DFO (2020a).

Figure 6 presents annual normalized anomalies averaged over the ice-free season, in which the contribution of each region is weighted according to its open-water area. The icefree season varies from as short as June to September in NAFO Division $2 \mathrm{G}$ to as long as March to November in NAFO Division 3P (seasonal information in the legend of Fig. 6). This time series corresponds to the SST contribution to the NLCI (normalized anomalies are colour coded at the bottom of the figure). This figure shows the colder than average conditions that prevailed in the early 1990s, with 1991 and 1992 being the coldest years of this time series. This period was followed by a predominance of warmer than average conditions that lasted until about 2014. In recent years, the period 2015-2019 (except for 2016) was colder than normal (defined as $\widetilde{\mathrm{SST}}<-0.5 \mathrm{SD}$ or blue colours at the bottom of Fig. 6). The year 2020 was, however, back to above-normal SST for the first time since 2014. 


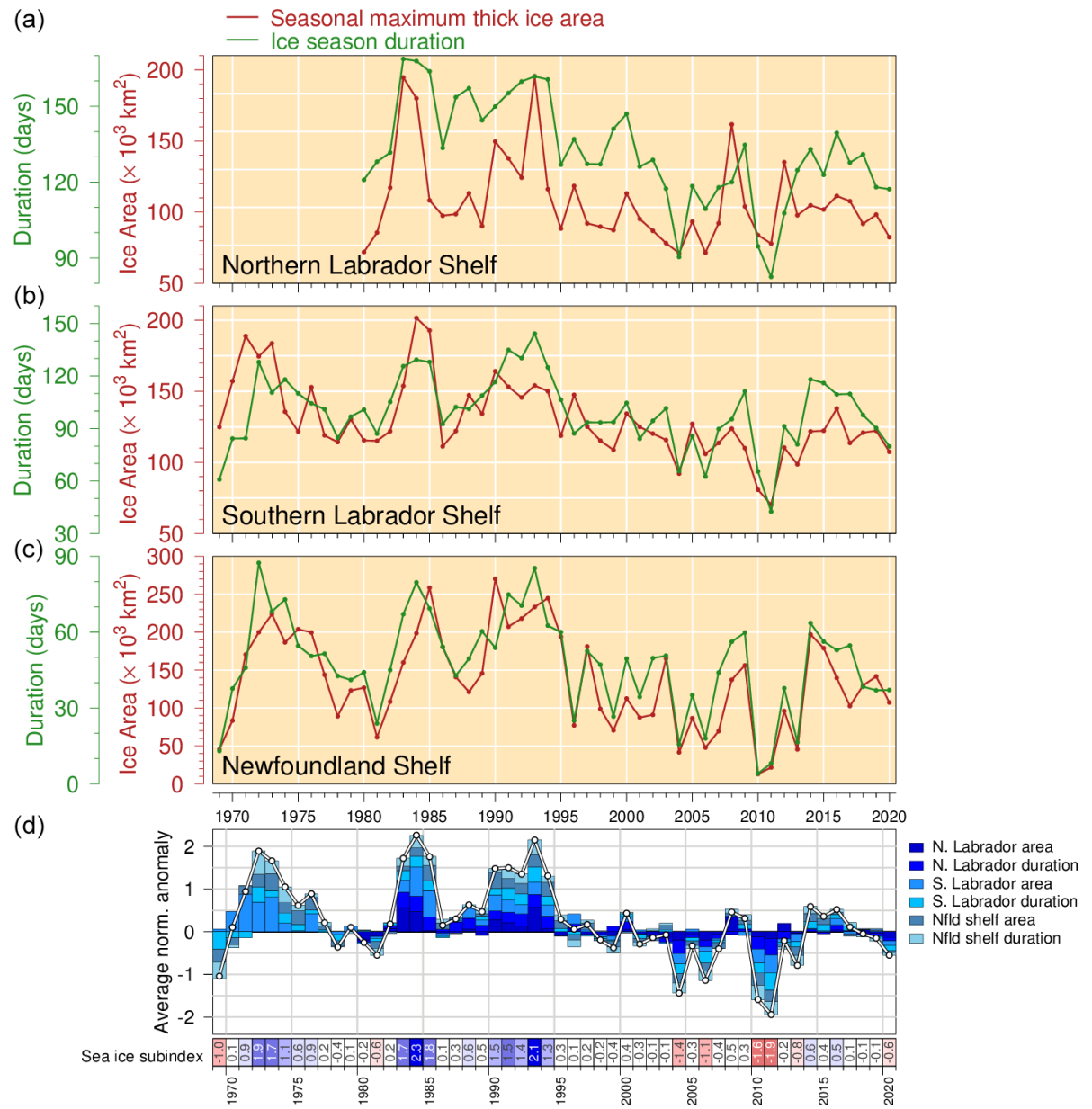

Figure 4. Sea ice season duration (green) and seasonal maximum area covered by thick ice (red) for the northern and southern Labrador shelves (a, b) and Newfoundland shelf (c). The northern Labrador time series starts in 1980, while the two others start in 1969. The six time series are transformed into normalized anomalies and presented in a stacked bar fashion in panel (d). The scorecard at the bottom of this last panel presents the numerical values of the mean normalized anomalies for each year. Here negative anomalies (indicative of warmer conditions) are coloured red and positive anomalies (colder conditions) blue. This time series is one component of the NL climate index.

\subsection{Station 27 data}

Station $27\left(47^{\circ} 32.8^{\prime} \mathrm{N}, 52^{\circ} 35.2^{\prime} \mathrm{W}\right)$ is located in the Avalon Channel just outside St. John's harbour, NL (Fig. 1). It is one of the longest hydrographic time series in Canada with frequent (near-monthly basis) conductivity-temperature-depth (CTD) observations since 1946. Station 27 was integrated into DFO's AZMP in 1999. In addition to sampling during these traditional hydrographic surveys, this station has been seasonally equipped with an automatic CTD profiling system installed on a surface buoy (type Viking) since 2017 (see Cyr et al., 2020, for further information).

Station occupations were first combined into monthly averaged temperature $(T)$ and salinity $(S)$ profiles from which the climatological annual cycle was extracted (Fig. 7). This figure shows the seasonal warming of the top layer $(\sim 20 \mathrm{~m})$, with temperature peaking in August before being mixed during the fall (Fig. 7a). Also visible in the temperature field is the cold intermediate layer (CIL), a prominent feature of the NL ecosystem (Petrie et al., 1988). The CIL is defined here as the water below $0{ }^{\circ} \mathrm{C}$ and delineated with a thick black contour in Fig. 7a. This layer originates in the winter as a cold surface layer which becomes isolated from the surface after the appearance of a seasonally heated surface layer during the spring (April-May). The CIL thus remains below the surface throughout most of the year, while its top boundary slowly deepens from about 50 to $100 \mathrm{~m}$ as the heat from the surface layer penetrates deeper into the water column. While in deeper areas of the NL shelf a third warmer layer is present beneath the CIL, at Station 27 the CIL generally extends down to the bottom $(\sim 176 \mathrm{~m})$. The summer CIL core temperature is defined as the minimum temperature of the monthly averaged profile for June, July and August (see below).

The surface salinity at Station 27 is generally lowest $(S<$ 31) between early September and mid-October (Fig. 7b). 


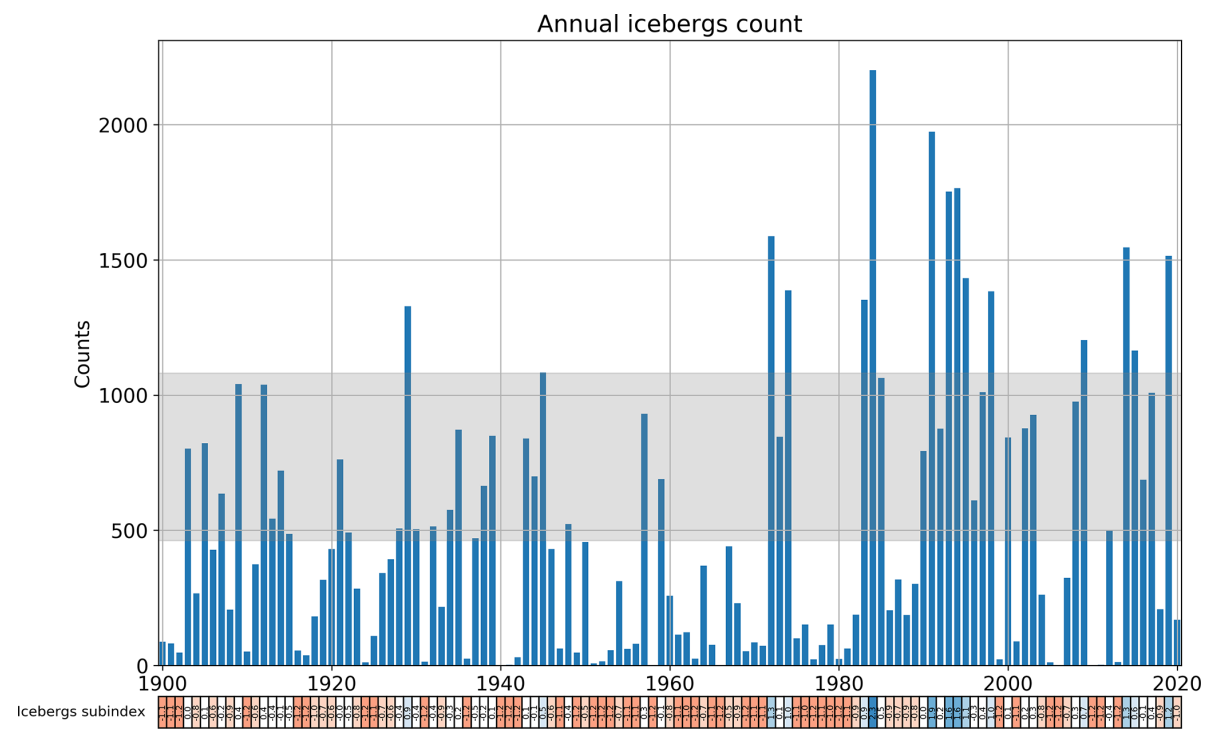

Figure 5. Annual iceberg count crossing south of $48^{\circ} \mathrm{N}$ on the northern Grand Bank. The shaded area corresponds to the 1991-2020 average $\pm 0.5 \mathrm{SD}$. The normalized anomaly of this time series is provided below the main panel under the form of a colour-coded scorecard. Here negative anomalies are red (generally corresponding to warmer conditions) and positive anomalies blue. This time series is one component of the NL climate index.

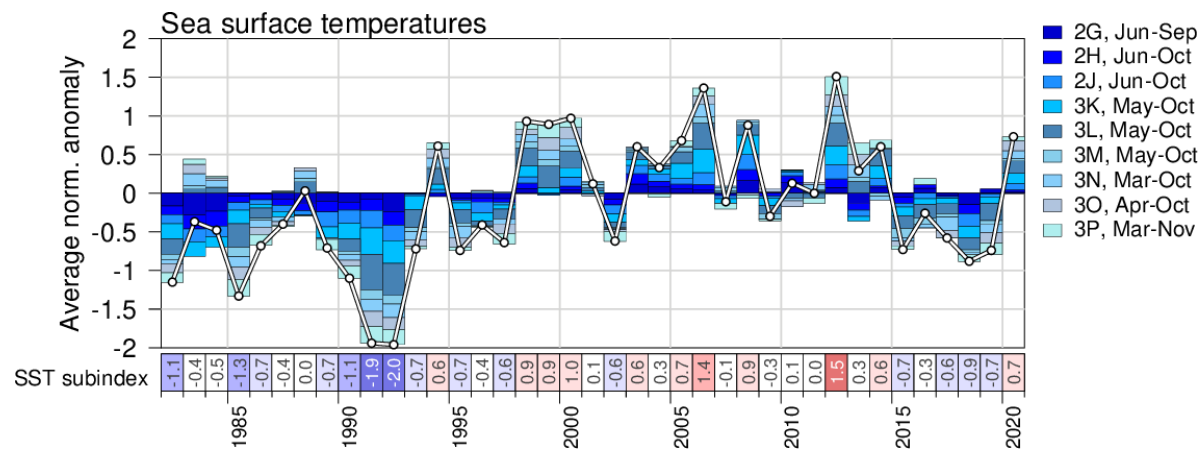

Figure 6. Sea surface temperature (SST) composite index in NAFO sub-areas 2 and 3 since 1982. This index is built by performing a spatially weighted average of the seasonal SST normalized anomalies for each NAFO division (divisions and months used are provided on the right-hand side of the figure). The numerical values of the normalized anomalies are provided in a colour-coded (red, warm; blue, cold) scorecard at the bottom. This time series is one component of the NL climate index.

These low near-surface salinities, generally from early summer to late fall, are prominent features of the salinity cycle on the Newfoundland shelf and are largely due to the melting of coastal sea ice upstream and carried over by the Labrador coastal current. Below the surface, the salinity at any depth increases in the spring and peaks in the summer before decreasing in the fall as a consequence of vertical mixing.

The data from Station 27, including the recent greater coverage obtained from Viking buoy automatic casts, contribute to three subindices of the NL climate index: vertically averaged $T$ and $S$ and the CIL core temperature (Fig. 8). The focus here is on the period starting in 1951 for which the seasonal coverage includes at least 8 months per year. Averages from 1980 and 1981 are excluded because of insufficient seasonal coverage (4 and 7 months, respectively). Data from 2020 have also been excluded because there were no station occupations during the first 6 months of the year due to the Covid-19 pandemic (first occupation occurred on 14 July, the latest start since 1946). In order to account for possible changes in seasonal coverage, the annual anomalies have been calculated as the average of monthly normalized anomalies.

The vertically averaged $(0-176 \mathrm{~m})$ temperature exhibits decadal-like cycles (Fig. 8a). The period between the mid1980s and mid-1990s struck as the coldest decade of the last 70 years. It was followed by a gradual warming trend that lasted 2 decades and peaked in 2011, the warmest year of this time series. The period from the mid-1960s and the early 1970 s was also marked by sustained warmer than normal temperatures. The end of this period coincided with 

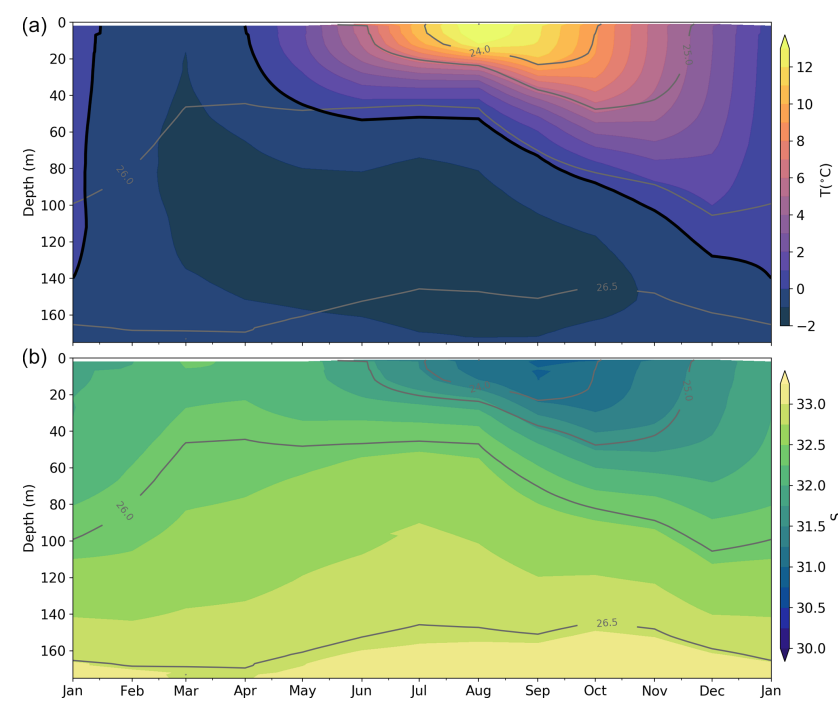

Figure 7. Climatological (1991-2020) annual cycle of temperature (a) and salinity (b) at Station 27. The grey contours are the isopycnals $\left(\sigma_{0}\right.$ in $\left.\mathrm{kg} \mathrm{m}^{-3}\right)$ derived from temperature and salinity using the TEOS-10 package (McDougall and Barker, 2011). The thick black line in (a) is the $0^{\circ} \mathrm{C}$ isotherm delimiting the top of the CIL.

the freshest anomaly on record at Station 27 observed in 1970 (Fig. 8b), an event coinciding with the Great Salinity Anomaly in the North Atlantic (Dickson et al., 1988). Similarly, the recent warmer than normal period (2010-2013) was followed by the second freshest anomaly on record observed in 2018. This most recent fresh anomaly on the NL shelf coincides with a large-scale salinity anomaly in the subpolar gyre (Holliday et al., 2020), but no clear causal relationship has been established between the two. The saltiest anomaly at Station 27 (1990) occurred during the cold period of the late-1980s and early 1990s.

The CIL subindex of Station 27 is also presented in Fig. 8c. This time series is the average normalized anomalies of the summer (June-August) CIL core temperature (minimum temperature of the monthly mean profile). The striking feature in this figure is the anomalously warm CIL anomaly present from the early 1960s to the mid-1970s. After the prevalence of a warm CIL in the early 2010s (with 2010 and 2011 being the warmest years since the 1970s), there has been a recent period of a return to near-normal conditions (roughly 2014-2017) that receded in 2018 and 2019. The CIL subindex of Station 27 has not been calculated for 2020.

\subsection{Cold intermediate layer on the NL shelf}

As mentioned above, the CIL is a prominent feature of the NL shelf. It is found almost everywhere in the subsurface during the summer. In order to highlight the influence of the CIL on the shelf as a whole, a proxy for its volume is es-
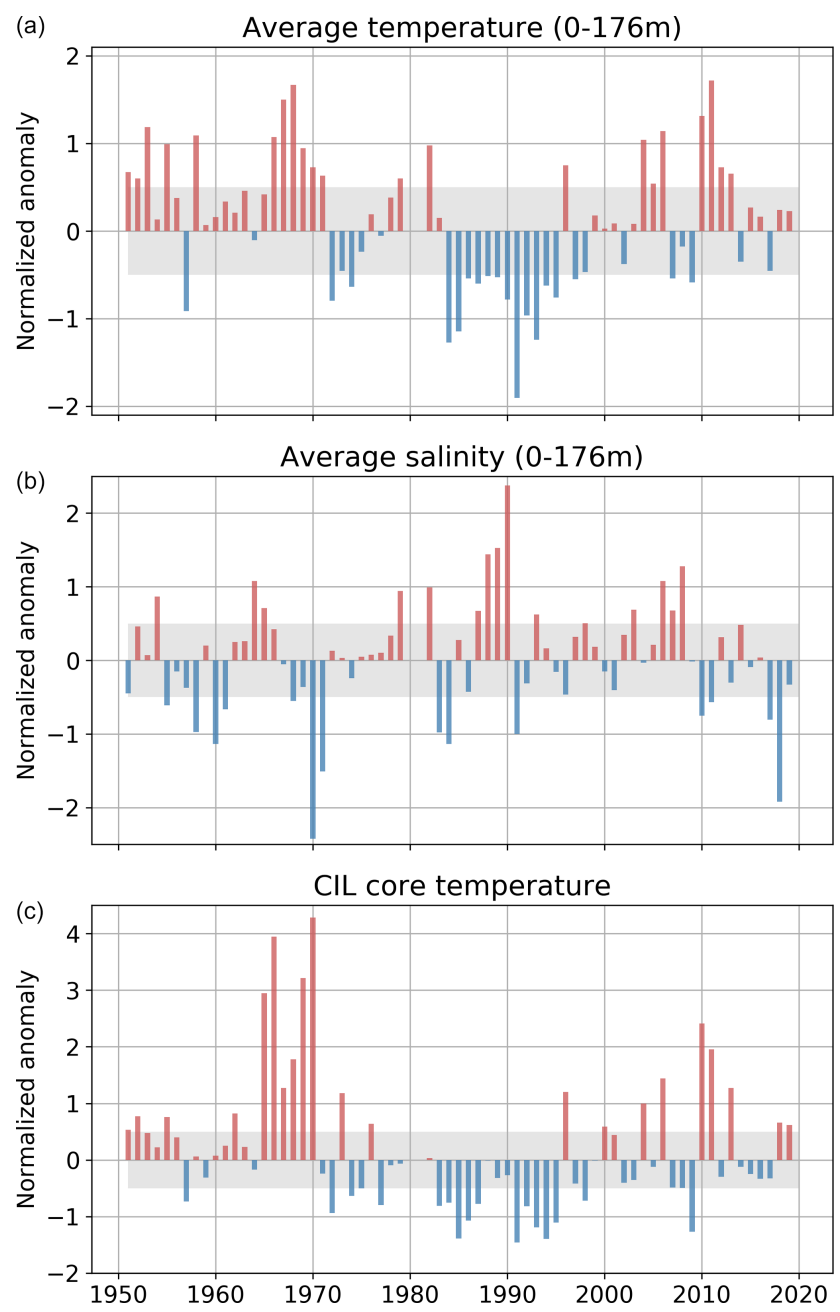

Figure 8. Normalized anomalies of the vertically averaged temperature (a) and salinity (b) and CIL core temperature (c) at Station 27. Shaded areas in all panels correspond to the 1991-2020 average $\pm 0.5 \mathrm{SD}$. These three time series are components of the NL climate index.

tablished using the area (in $\mathrm{km}^{2}$ ) of water below $0{ }^{\circ} \mathrm{C}$ along Seal Island (SI), Bonavista Bay (BB) and Flemish Cap (FC) hydrographic sections (Fig. 1). These sections were selected because they have been systematically surveyed since the early 1950 s before being formerly standardized by the International Commission for the Northwest Atlantic Fisheries in 1976 (ICNAF, 1978). Since 1999, these hydrographic sections have been monitored by DFO as part of the AZMP.

Figure 9 shows the summer temperature along section SI during 2 extreme years, the warm 1965 and the cold 1990. The 1991-2020 climatology is also presented. For each sampled summer, the CIL area (e.g. the area of the section delimited by the thick black contour in Fig. 9) was calculated. For example, in 1990, the area of the CIL was $26.9 \mathrm{~km}^{2}$, while it was only $1.5 \mathrm{~km}^{2}$ in 1965 . This shows the amplitude of the interannual variability of the CIL and its potential influence 

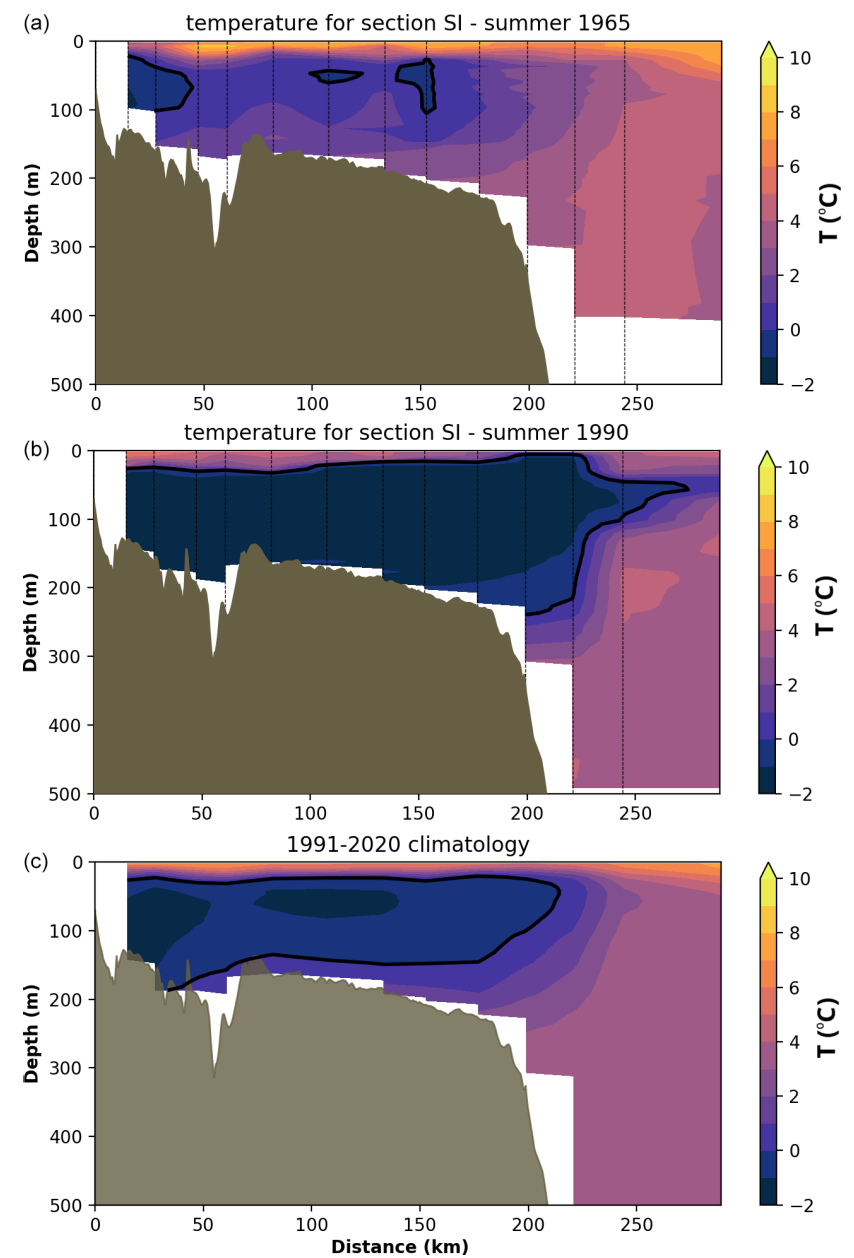

Figure 9. Summer temperature along hydrographic section Seal Island (SI) during 1965 (a), 1990 (b) and the 1991-2020 average (c). The vertical axis is limited to the top $500 \mathrm{~m}$, and the horizontal axis is the distance (in $\mathrm{km}$ ) from the coast. The $\mathrm{CIL}\left(T<0^{\circ} \mathrm{C}\right)$ is highlighted with a thick black contour. Station locations are indicated with thin dashed lines.

on the ecosystem. In 1990, most of the sea floor along section SI was in direct contact with the CIL and water below $-1{ }^{\circ} \mathrm{C}$. In 1965, when the CIL was small and fragmented, none of the sea floor was in contact with the CIL, and the bottom conditions were in consequence several degrees warmer than in 1990.

The normalized anomalies of the CIL area for sections SI, BB and FC are presented in Fig. 10. This figure highlights again the warmer conditions (negative anomalies) of the 1960s and the colder conditions of the mid-1980s and early 1990s. The average of the normalized anomalies are shown in a scorecard at the bottom of the main panel and correspond to the CIL area contribution to the NLCI.

\subsection{Bottom temperature}

Canada has been conducting random stratified trawl surveys in NAFO sub-areas 2 and 3 of the NL shelf since 1971 (Doubleday, 1981). Since 1980, temperature (and salinity since 1990) measurements have been available for most of these fishing sets thanks to trawl-mounted CTD observations. The scientific trawl surveys target NAFO Subdivision 3Ps (south coast of Newfoundland) and Division 3LNO (Grand Banks) during the spring surveys and Divisions $2 \mathrm{H}$ (northern Labrador), 2J (southern Labrador), 3K (eastern Newfoundland) and 3LNO (Grand Banks) during the fall (see map Fig. 1). These surveys, combined with other available data from multiple sources (see below), are used to provide largespatial-scale oceanographic information of the NL shelf, including information on the bottom habitat parameters of numerous commercial species (e.g. Cyr et al., 2020).

The method used to derive the bottom temperature was introduced by Cyr et al. (2019) and is briefly summarized here. First, all available annual profiles of temperature (scientific trawl surveys, AZMP hydrographic campaigns, surveys from other DFO regions, international oceanographic campaigns, expendable bathythermographs, Argo program, etc.) are vertically averaged in $5 \mathrm{~m}$ bins and vertically interpolated to fill missing bins. Then, for each season (AprilJune for spring and September-December for fall), all data are averaged on a regular $0.1^{\circ} \times 0.1^{\circ}$ (latitudinal $\times$ longitudinal) grid to obtain one seasonal profile per grid cell. Since this grid has missing data in many cells, each depth level is horizontally linearly interpolated. For each grid point deeper than $10 \mathrm{~m}$, the bottom observation is considered as the data at the closest depth to the GEBCO 2014 Grid bathymetry (version 20141103) to a maximum $50 \mathrm{~m}$ difference. In order to only focus on the shelf, observations deeper than $1000 \mathrm{~m}$ are clipped. This method is applied for all years between 1980 and 2020 from which the 1991-2020 climatology is also derived. In order to match the scientific surveys schedule, the normalized anomalies of bottom temperature are calculated separately for NAFO Divisions 3Ps and 3LNO in the spring and $2 \mathrm{H}, 2 \mathrm{~J}, 3 \mathrm{~K}$ and $3 \mathrm{LNO}$ in the fall. The time series of the bottom temperature for both seasons is presented in a stacked bar plot in Fig. 11. This figure shows the cold phase from the mid-1980s to the mid-1990s, followed by a warmer phase that peaked in 2011. A scorecard at the bottom of this figure presents the mean normalized anomalies. The latter corresponds to the bottom temperature contribution to the NLCI.

\section{Discussion}

Figure 12 presents the NLCI. In Figure 12a, the 10 subindices described in the previous section are colour coded according to their normalized anomaly: $<0.5 \mathrm{SD}$ in blue, $>0.5 \mathrm{SD}$ in red, and everything within $\pm 0.5 \mathrm{SD}$ in white. Note that for some indices where positive anomalies generally indicate colder conditions (e.g. sea ice), the natural sign of the 


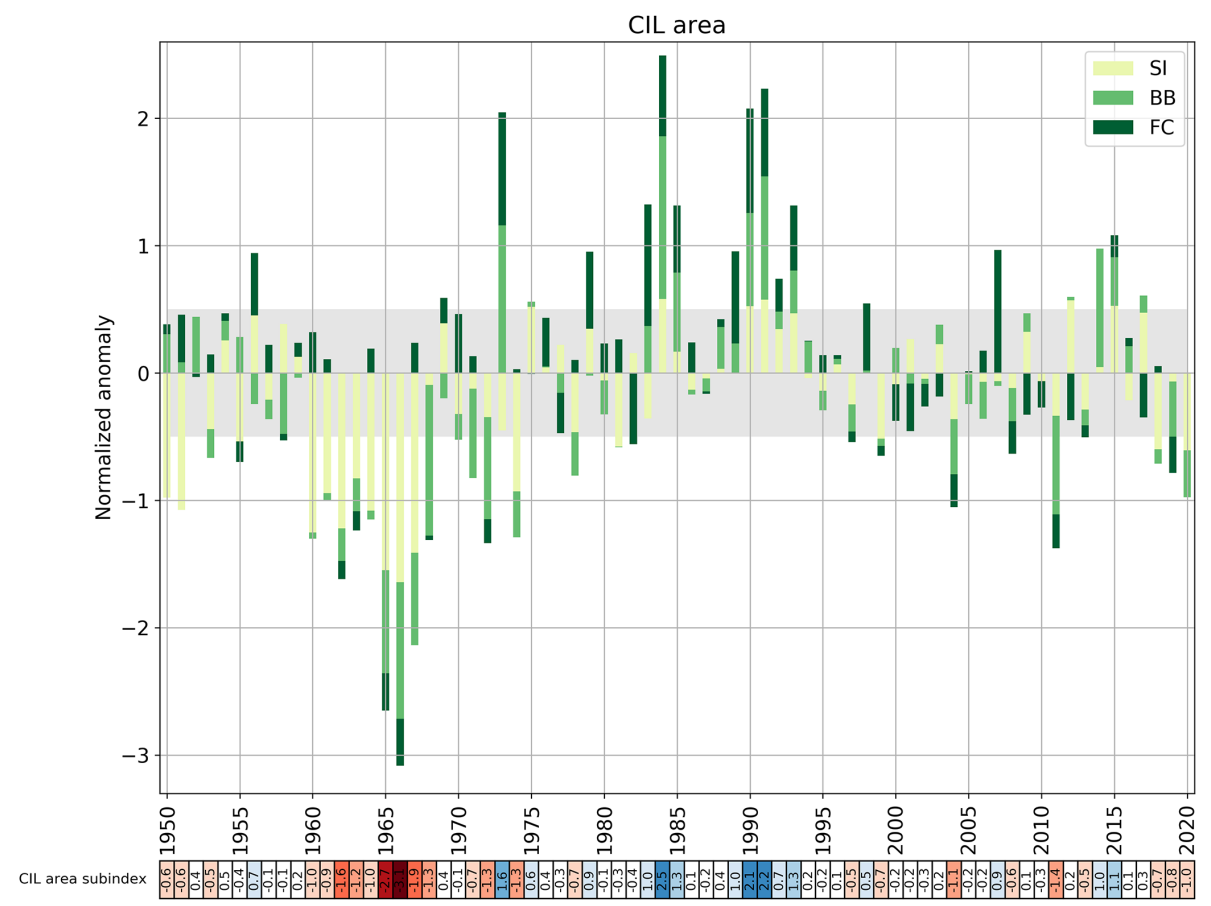

Figure 10. Normalized anomalies of the mean CIL area for hydrographic sections Seal Island (SI), Bonavista Bay (BB) and Flemish Cap (FC). This time series correspond to the average of the three sections, in which the contribution of each section is represented. The shaded area corresponds to the 1991-2020 average $\pm 0.5 \mathrm{SD}$. The numerical values of this time series are reported in a colour-coded scorecard at the bottom of the figure. Here negative anomalies (generally corresponding to warmer conditions) are coloured red and positive anomalies blue. This time series is one component of the NL climate index.

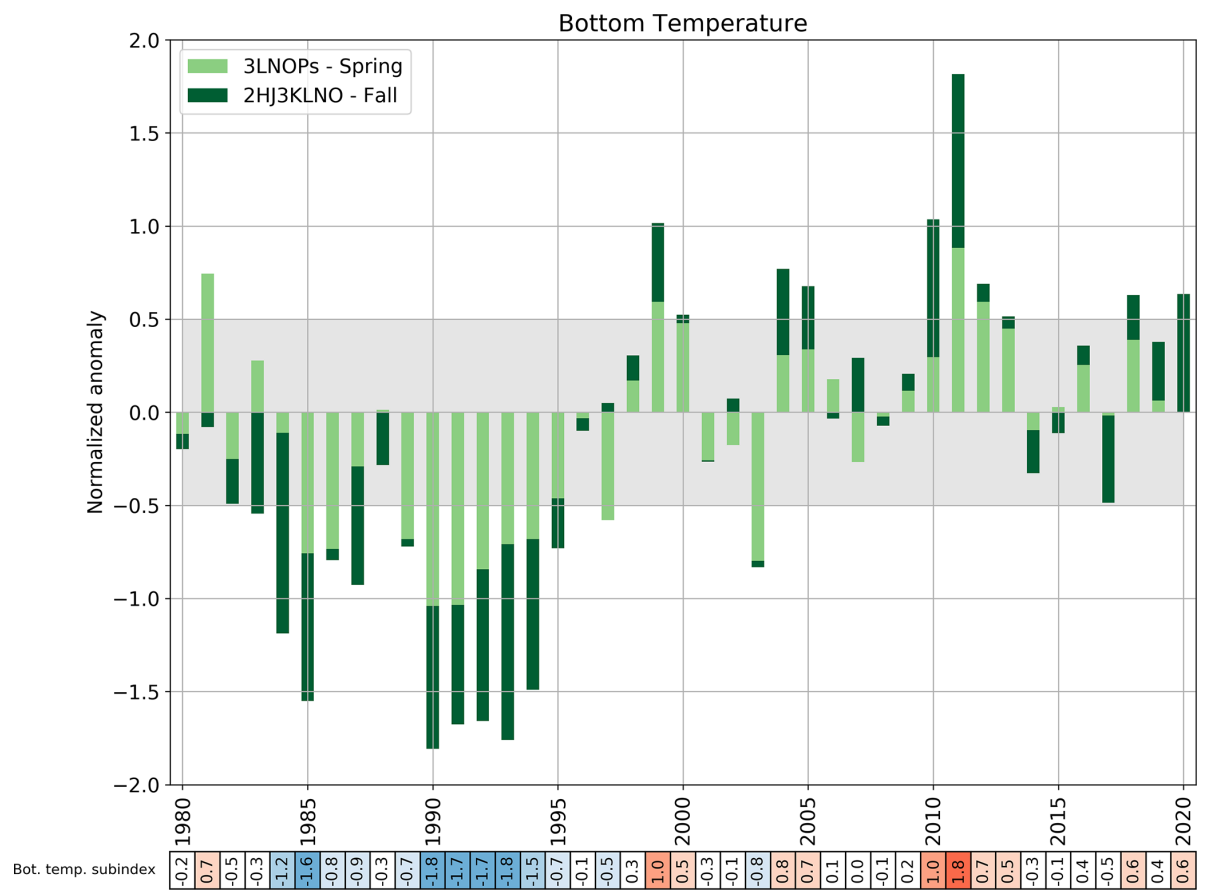

Figure 11. Normalized anomalies of bottom temperature in NAFO Divisions 3LNOPs (spring) and 2HJ3KLNO (fall). This time series corresponds to the average of the two seasons, in which each contribution is represented. The shaded area corresponds to the 1991-2020 average $\pm 0.5 \mathrm{SD}$. The numerical values of this time series are reported in a colour-coded scorecard at the bottom of the figure. This time series is one component of the NL climate index. 


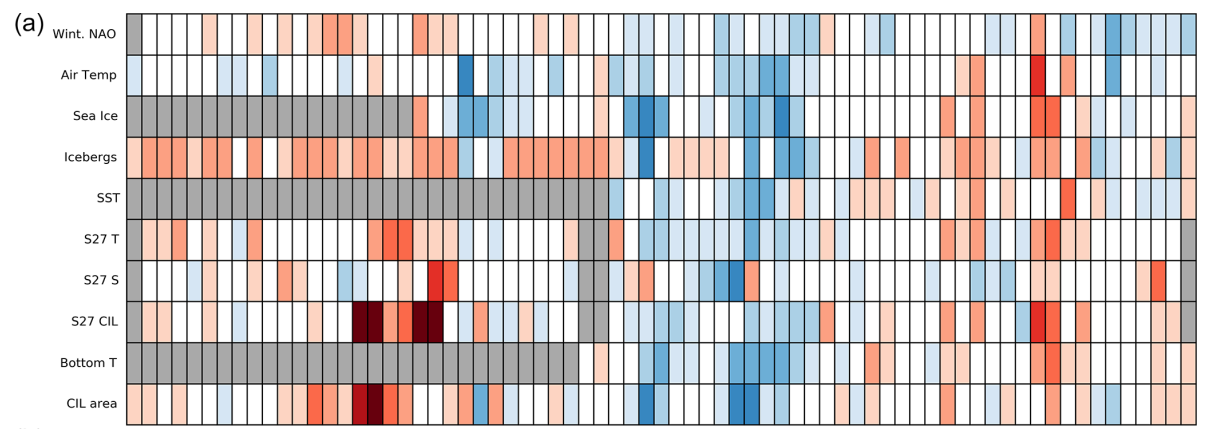

(b)

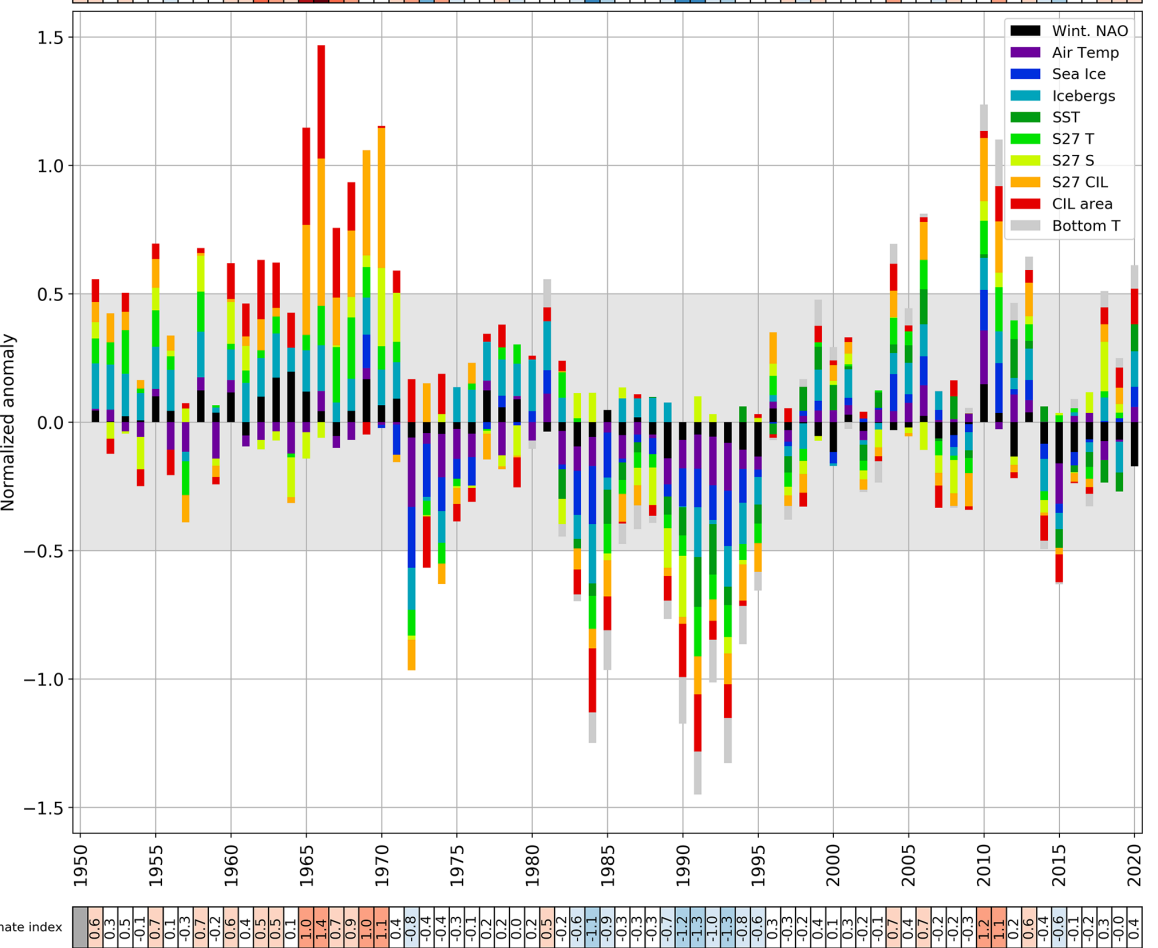

Figure 12. Newfoundland and Labrador climate index described in this study. The scorecard in panel (a) represents the 10 subindices used to construct the climate index, colour coded according to their value (blue negative, red positive, white neutral). These time series are the following: winter NAO index (starts in 1951), the air temperature at five sites (starts in 1950), the sea ice season duration and maximum area for the northern Labrador, southern Labrador and Newfoundland shelves (starts in 1969), the number of icebergs (starts in 1950), SSTs in NAFO Division 2GHJ3KLNOP (starts in 1982), vertically averaged temperature and salinity at Station 27, CIL core temperature at Station 27 (starts in 1951), the summer CIL areas on the hydrographic sections Seal Island, Bonavista Bay and Flemish Cap (starts in 1950), and the spring and fall bottom temperature in NAFO Divisions 3LNOPs and 2HJ3KLNO, respectively (starts in 1980). The sign of some indices (NAO, ice, icebergs, salinity and CIL volume) has been reversed when positive anomalies are generally indicative of colder conditions. Grey cells in the scorecards indicate the absence of data. Panel (b) represents the climate index in a stacked-bar fashion, in which the total length of the bar is the average of the respective subindices and in which their relative contribution to the average is adjusted proportionally. The scorecard at the bottom of the figure shows the colour-coded numerical values of the climate index.

components has been reversed such that a positive value now corresponds to warm conditions (see figure caption). The subindices in their natural signs are also provided in the dataset. Figure 12b shows a stacked bar plot where annual NLCI values are represented by the total length of the bar (arithmetic average of all subindices available for a certain year), while individual colours have been adjusted to represent the relative contribution of each subindex to the NLCI.
Numerical values of the NLCI are also reported in single a scorecard at the bottom of the figure.

The NLCI highlights the different regimes prevailing on the NL shelf and the Northwest Atlantic since 1951. For example, the 1960s stands out as the warmest decade of the entire 1951-2020 period, although it is heavily driven by CIL anomalies. The following few decades were gradually cooling until the early 1990s, with 1991 being the coldest year on record since 1951. The warming trend that followed the 


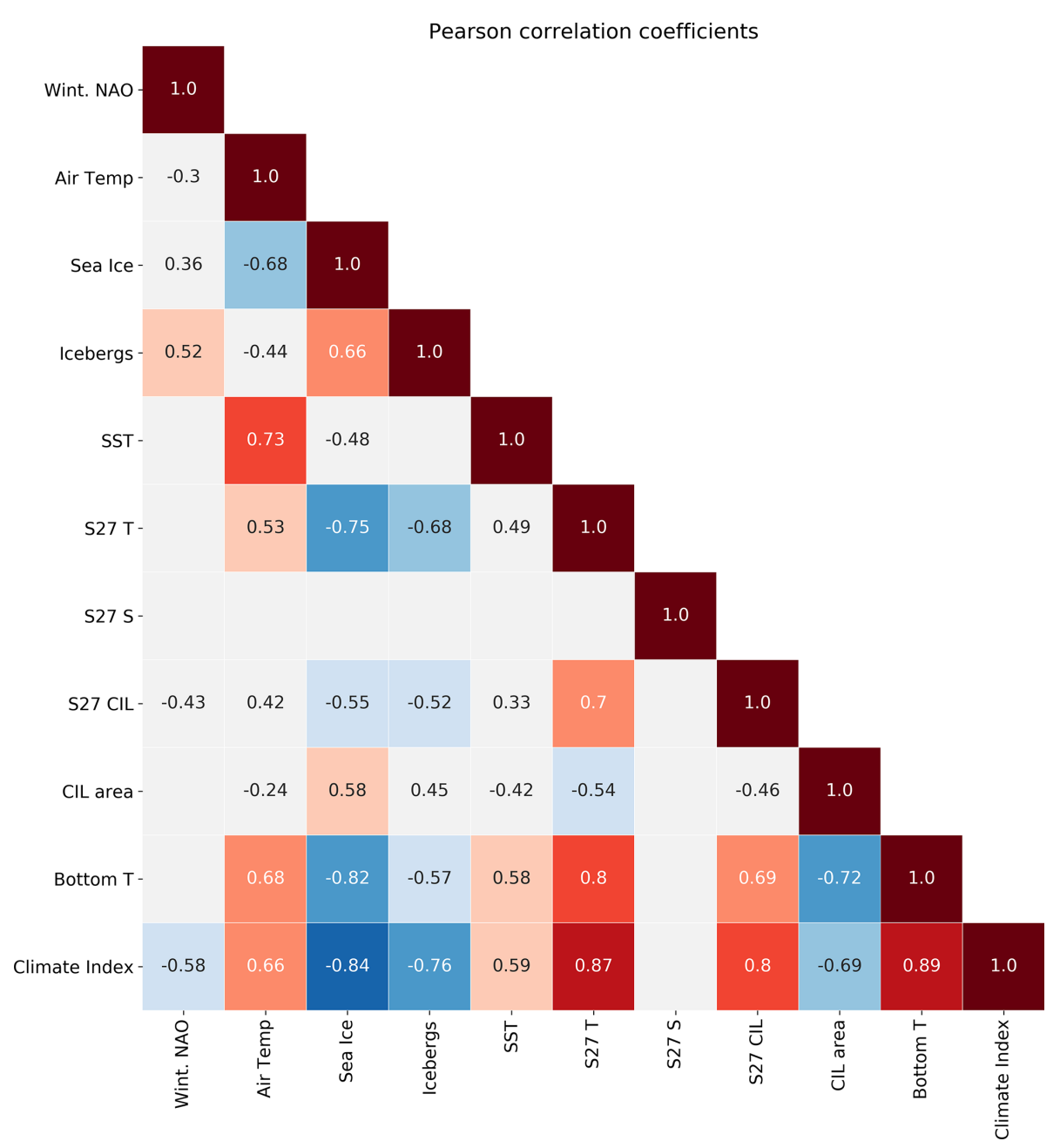

Figure 13. Pearson correlation $(r)$ matrix between the different subindices of the NL climate index and the NL climate index itself. Red and blue colours denote a positive and negative correlation, respectively. Only significant correlations ( $p$ values $<0.05)$ are shown. Correlations less than \pm 0.5 have been left white. The natural signs (not reversed) of the subindices have been used here in order to illustrate relationships in which positive (warm) anomalies in one variable (e.g. Station 27 temperature) are reflected by negative anomalies in another (e.g. sea ice).

early 1990s peaked in 2010-2011 (depending on the record) and was followed by recent cooling that culminated in 2015. This recently observed cold period on the NL shelf (roughly 2014-2017) was the coldest period since the early 1990s (Cyr et al., 2020) and coincided with the intensification of convection in the Labrador Sea that created the largest volume of Labrador Sea Water since the early 1990s (Yashayaev and Loder, 2017).

The correlations among the different subindices are presented in Fig. 13. This shows the interactions between the different components of the NLCI while giving insights into the functioning of the NL shelf climate. The vertically averaged temperature at Station 27 is well correlated with the bottom temperature on the NL shelf $(r=0.80)$ and with the core temperature of the CIL $(r=0.70)$. The temperature at Station 27 is also negatively correlated with sea ice $(r=-0.75)$. This is because the harshness of the winter has a direct con- sequence on the sea ice production and the production of the CIL water. Because the CIL is in direct contact with the sea floor on a large portion of the NL shelf, it has a direct influence on its bottom temperature. It is thus not surprising that the bottom temperature of the NL shelf is also negatively correlated with sea ice $(r=-0.82)$. Finally, because the air temperature has a direct influence on both SST and sea ice, the correlation is good $(r=0.73$ and $r=-0.68$, respectively) with these variables even if the annual air temperature average is used (i.e. includes both winter and summer). Interestingly, the winter NAO is not well correlated with any of the variables $(r<0.5)$ except slightly with the number of icebergs $(r=+0.52)$. While the winter NAO is expected to capture some decadal dynamics (warm 1960s and early 2010s; cold 1990s and late 2010s), the weak correlation between the NAO and the different NLCI components suggests that lag or inertial effects are important on the NL shelf (e.g. it takes 
several consecutive cold winters to build an important volume of cold water). It also suggests that the NLCI captures other types of variability specific to the NL shelf compared to the winter NAO alone. The good correlation between Station 27 temperature and other components of the climate index adds weight to numerous studies suggesting that this station is representative of the large-scale climate of the NL shelf (e.g. Petrie et al., 1991, 1992; Colbourne et al., 1994; Drinkwater, 1996; Han et al., 2015).

Figure 13 also includes the correlation coefficients between the NLCI index and all its subindices. Although a visual examination of Fig. 8 shows matching warm/fresh and cold/salty periods at Station 27, salinity is not significantly correlated with any of the subindices of the NLCI. This suggests that the relation between freshwater and water temperature do not operate on a year to year basis but may be lagged or relevant on longer (e.g. decadal) timescales. Salinity was, however, kept in the NLCI because it has recently been shown to be a useful predictor for the NL ecosystem (e.g. Murphy et al., 2021 on capelin spawning dynamics) and because freshwater fluxes on the NL shelf are an important contribution to the freshwater budget of the North Atlantic, with consequences on the North Atlantic overturning circulation (Florindo-López et al., 2020). Because the 10 subindices are provided here, users of the NLCI can, however, recompute their own climate index using any combination of the subindices. Except for salinity at Station 27, the correlation coefficient between the NLCI and its subindices varies between $|r|=0.58$ and $|r|=0.89$, the latter with the NL shelf bottom temperature. The absence of very strong correlation (e.g. $|r|>0.90$ ) between the different subindices, and between any subindex and the climate index itself, shows the relative independence of the different components of the climate index and gives confidence in the choices made for its design.

Finally, there is a good correlation $(r=0.87)$ between this new climate index and the averaged version of the CEI used until recently (e.g. Cyr et al., 2019), ensuring continuity with previous studies using this index (Fig. 14). A notable difference between the two indices, however, is that the variance of the former $\left(\sigma^{2}=1.2\right)$ is larger than that of the latter $\left(\sigma^{2}=0.4\right.$; note the different vertical axis systems in Fig. 14). It is likely that the greater independence of the components used here reduces the variance of the new climate index compared with the previous CEI that used 28 components, some being highly correlated (e.g. air temperature at four sites, SST in overlapping or close areas, bottom temperature and salinity in neighbouring regions, etc.).

\section{Code availability}

The codes used to develop the subindices are interconnected mixtures of Python, shell scripts (tcsh and bash), Make, Perl

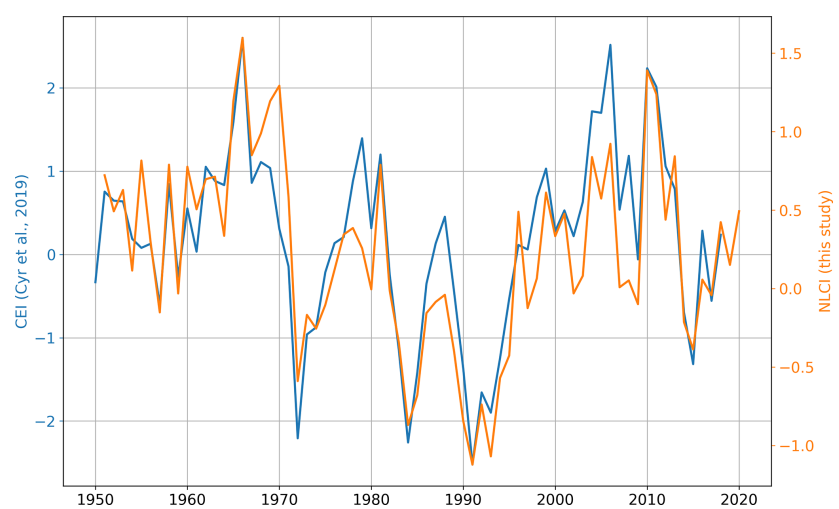

Figure 14. Comparison between the Composite Environmental Index (CEI) used until recently (e.g. Cyr et al., 2019) and the new NL climate index introduced here. Note the difference vertical axis systems. The correlation between the CEI and the NLCI is $r=0.87$. Note that in order to be consistent with the last version of the CEI, the NLCI based on the 1981-2010 climatology was used here. The CEI is also presented here as the average of the 28 components rather than their sum.

and awk that are difficult to make available on a public repository. Please contact the authors for any related question.

\section{Data availability}

The data presented in this study are available here: https://doi.org/10.20383/101.0301 (Cyr and Galbraith, 2020). Three comma-separated value (CSV) files are provided:

- NL_climate_index.csv contains annual values of the NL climate index.

- NL_climate_index_all_fields.csv contains annual values of the 10 subindices making up the NL climate indices (with some signs reversed; see Fig. 12 caption). The average of these 10 subindices corresponds to the NL climate index.

- NL_climate_index_all_fields_natural_signs.csv contains annual values of the 10 subindices making up the NL climate indices in line with their natural sign.

For the foreseeable future, this index will be updated on an annual basis once the update from the previous year is completed (e.g. targeted release in the spring of the following year).

\section{Conclusions}

This article describes a new climate index for the Newfoundland and Labrador shelf. This index is composed of 10 
subindices representing different aspect of the NL ecosystem: winter NAO, air temperature, sea ice season severity, iceberg count, SST, Station 27 temperature, salinity and CIL core temperature, CIL area on three hydrographic sections, and bottom temperature on the NL shelf. Some subindices are season specific (e.g. winter NAO, icebergs and sea ice season severity), while others are representative of the entire annual cycle (e.g. air temperature and seasonal SST), which may mask strong seasonal contrasts during some years. Because the NLCI and all 10 subindices are made available, users can derive their own custom index by averaging any combination of subindices. It is expected that this new index will be useful for ecosystem studies, stock assessments, forecast models of marine resources and more. 


\section{Appendix A: Figures using 1981-2010 climatology}

The change in the climatological period from 1981-2010 to 1991-2020 is a shift towards a warmer reference period (exclusion of the cold mid-1980s and inclusion of the warmer mid-2010s). The consequences of this shift for the different subindices is generally an exacerbation of the colder anomalies and a reduction in the amplitude of the warmer anomalies. This appendix provides alternate versions of the figures provided in the paper that used a 1991-2020 climatology but this time using the previous climatological period of 19812010.

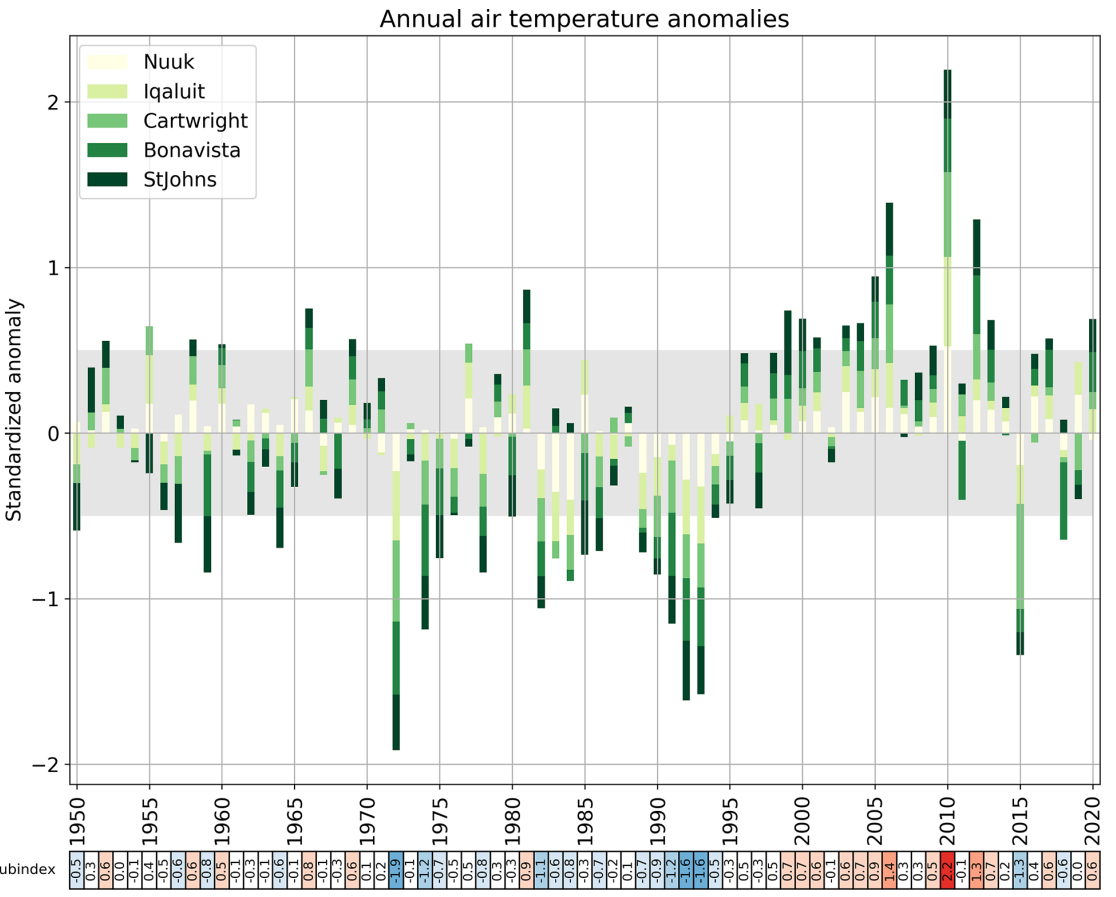

Figure A1. Same as Fig. 3 but using a climatology referenced to the 1981-2010 period. 

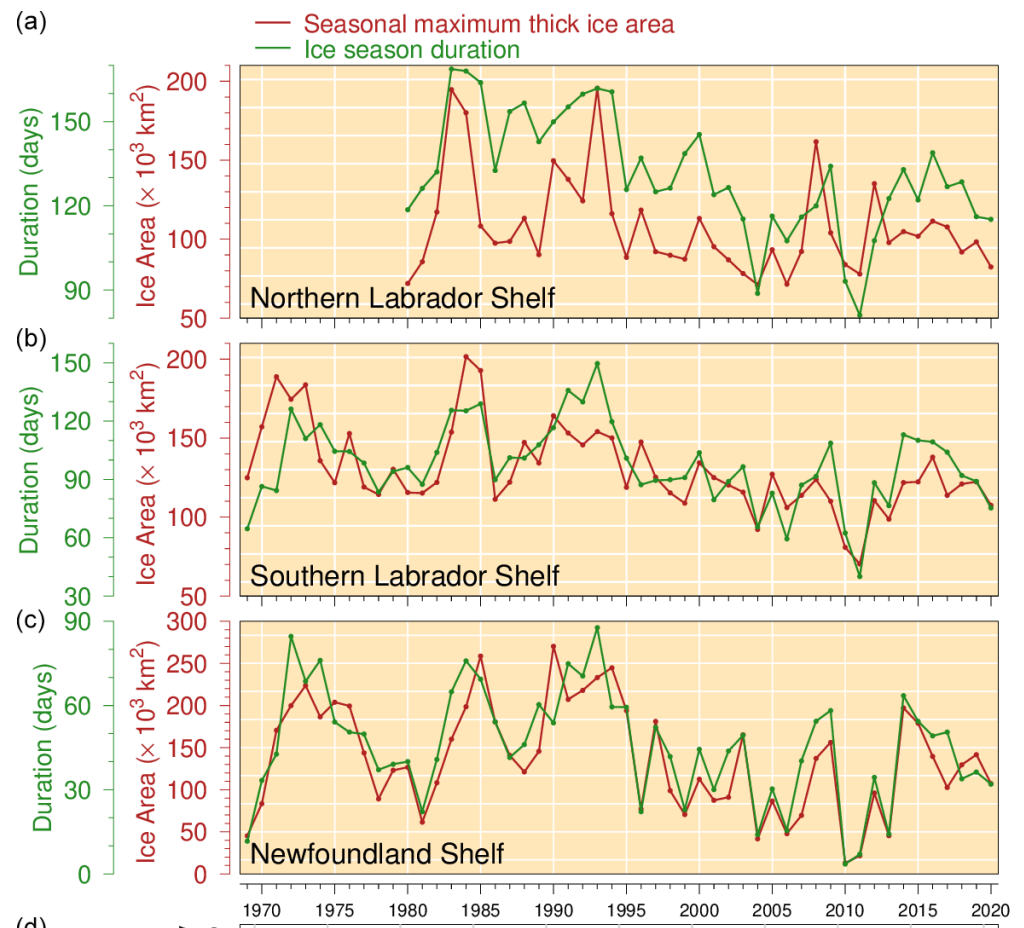

(d)

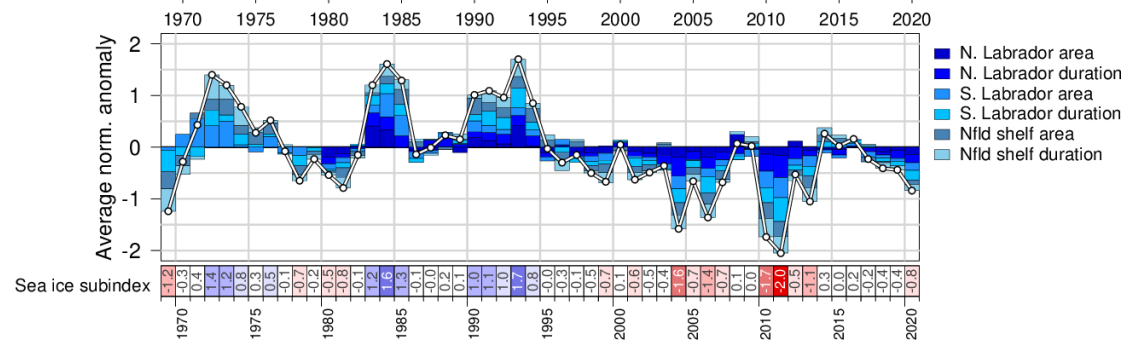

Figure A2. Same as Fig. 4 but using a climatology referenced to the 1981-2010 period.

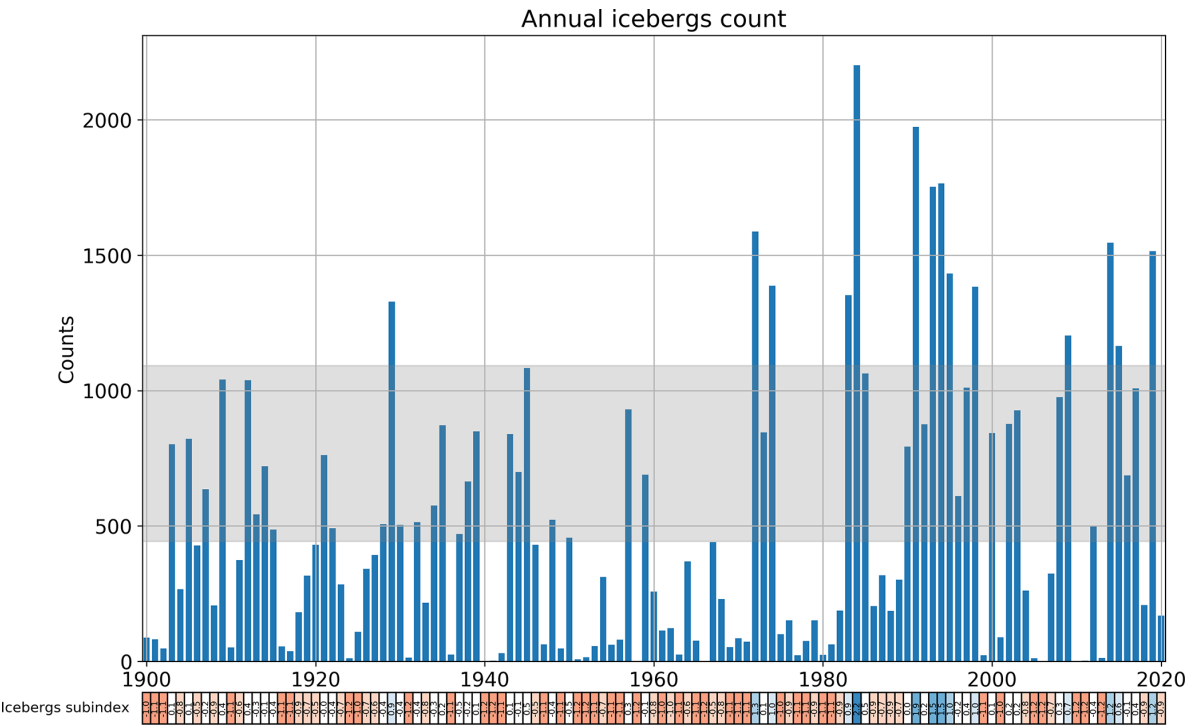

Figure A3. Same as Fig. 5 but using a climatology referenced to the 1981-2010 period. 


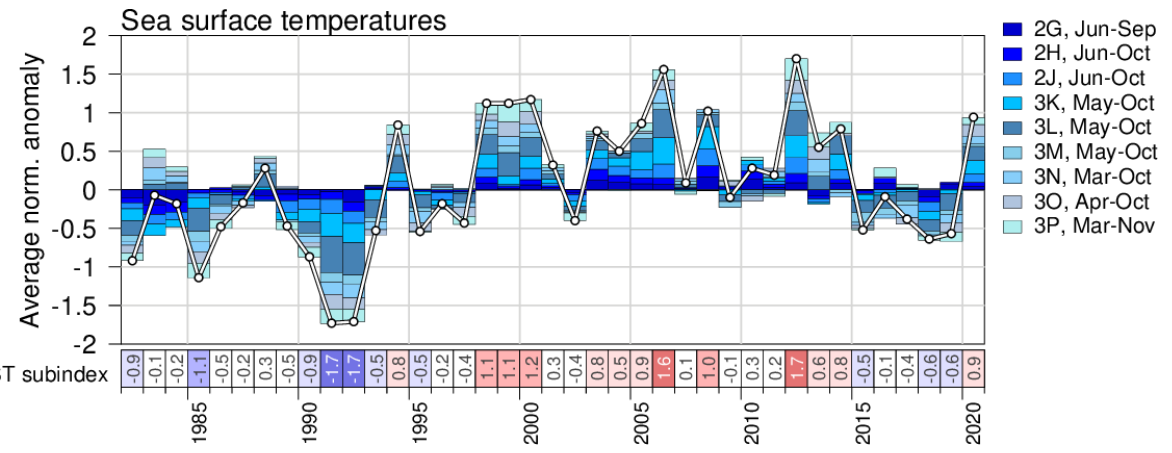

Figure A4. Same as Fig. 6 but using a climatology referenced to the 1981-2010 period.
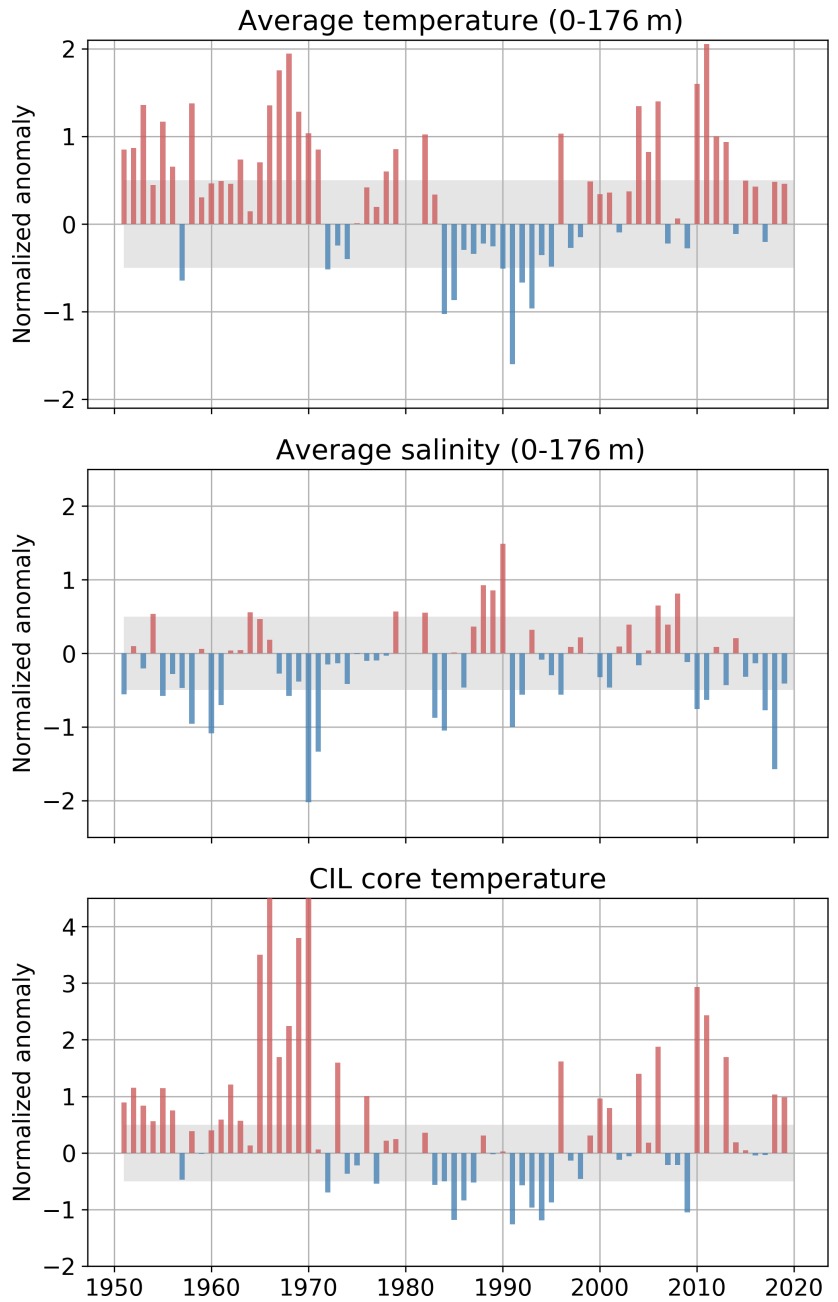

Figure A5. Same as Fig. 8 but using a climatology referenced to the 1981-2010 period. 


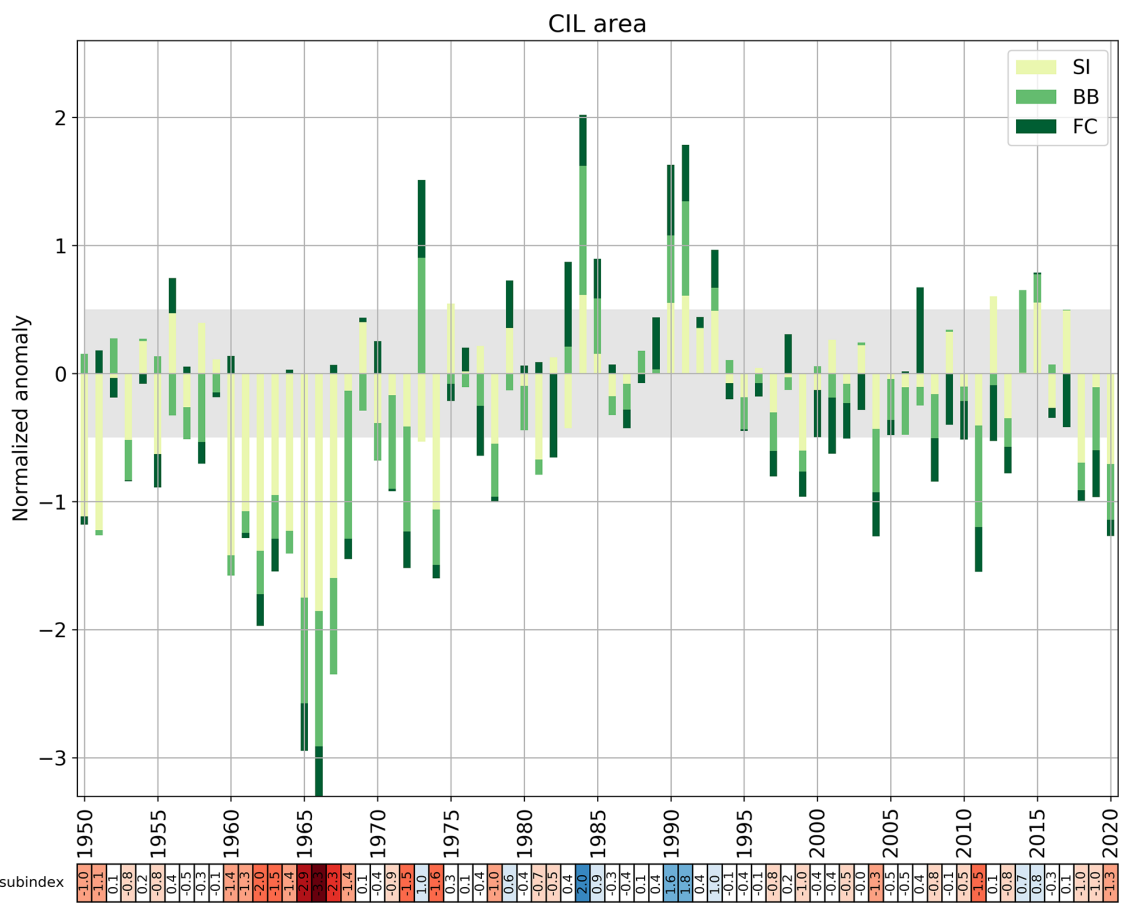

Figure A6. Same as Fig. 10 but using a climatology referenced to the 1981-2010 period.

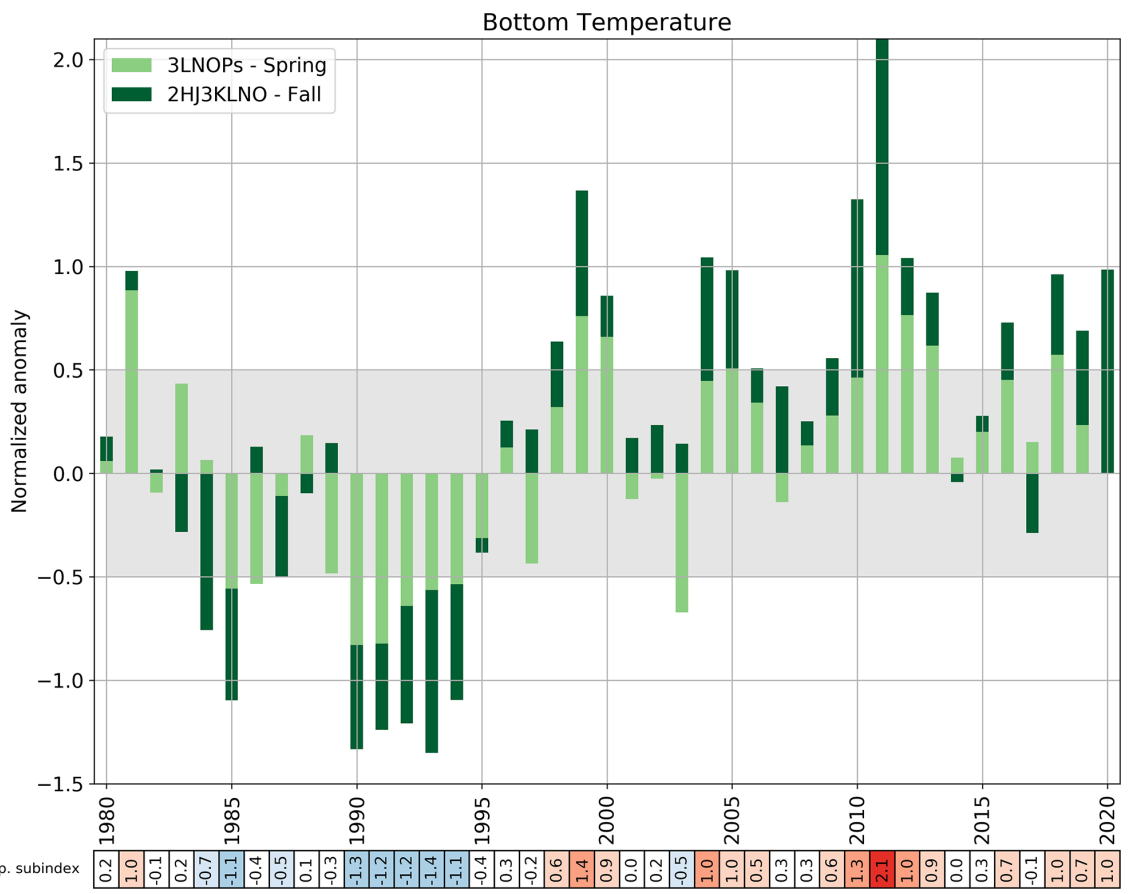

Figure A7. Same as Fig. 11 but using a climatology referenced to the 1981-2010 period. 


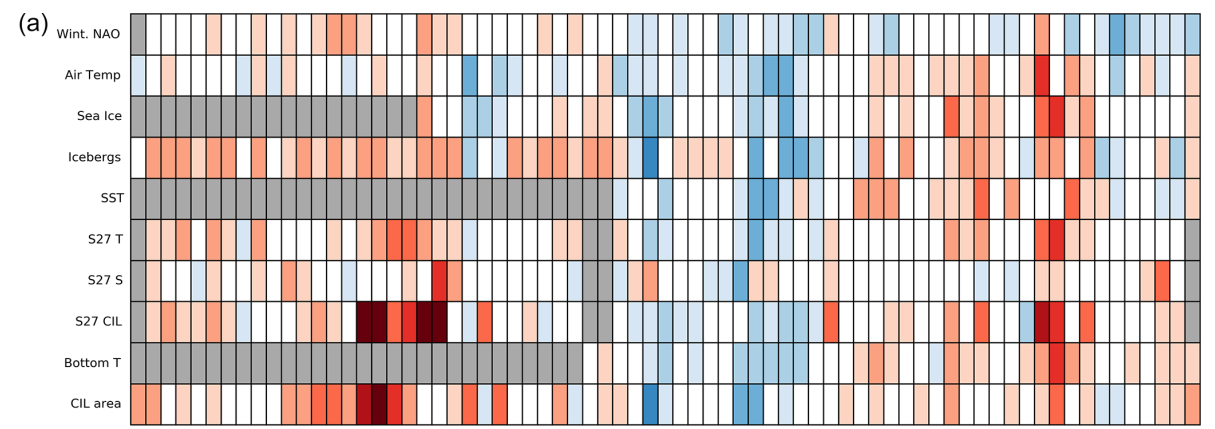

(b)

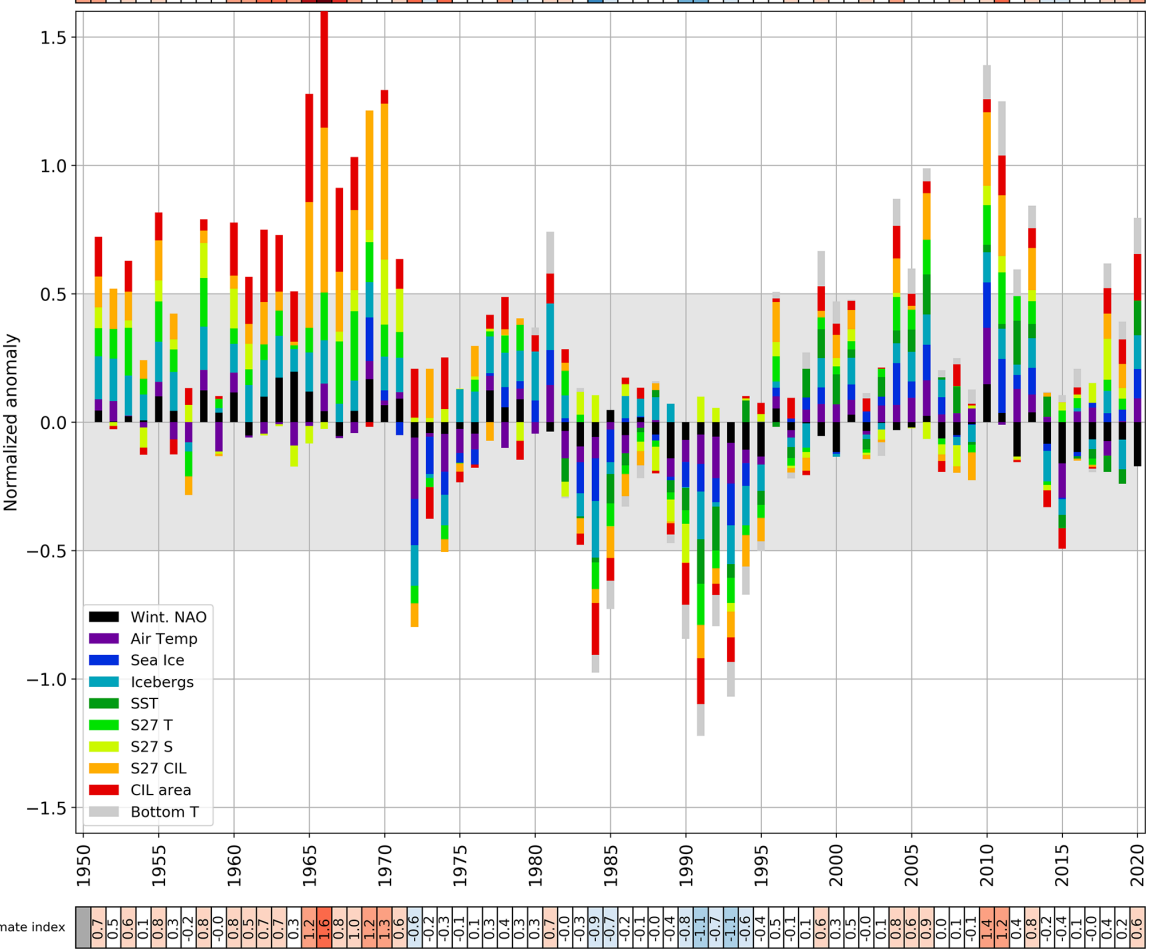

Figure A8. Same as Fig. 12 but using a climatology referenced to the 1981-2010 period. 
Author contributions. FC designed the study, led the writing and calculated most of the subindices. PSG calculated the SST and the sea ice subindices and participated in the writing. Both authors discussed in depth the science, technical details and the structure of this article.

Competing interests. The authors declare that they have no conflict of interest.

Acknowledgements. This work is a contribution to the Atlantic Zone Monitoring Program (AZMP) of Fisheries and Oceans Canada (DFO). The authors thank the numerous scientists, technicians, captains and crew members who have participated in the sampling and analysis effort since 1951. The authors also thank Pierre Pepin, who provided comments on an early version of the manuscript, and Bee Berx and two anonymous reviewers for their valuable comments on the study.

Review statement. This paper was edited by Giuseppe M. R. Manzella and reviewed by Barbara Berx and two anonymous referees.

\section{References}

Colbourne, E., Narayanan, S., and Prinsenberg, S.: Climatic changes and environmental conditions in the Northwest Atlantic, 1970-1993, ICES Journal of Marine Science Symposia, 198, 311-322, 1994.

Colbourne, E., Craig, J., Fitzpatrick, C., Senciall, D., Stead, P., and Bailey, W.: An assessment of the physical oceanographic environment on the Newfoundland and Labrador Shelf during 2005, Canadian Science Advisory Secretariat Research Document, 2006/030, ii + 14 pp., Fisheries and Oceans Canada, Ottawa, Canada, 2006.

Colbourne, E., Craig, J., Fitzpatrick, C., Senciall, D., Stead, P., and Bailey, W.: An assessment of the physical oceanographic environment on the Newfoundland and Labrador Shelf during 2006, Canadian Science Advisory Secretariat Research Document, 2007/030, iv + 14 pp., Fisheries and Oceans Canada, Ottawa, Canada, 2007.

Colbourne, E., Craig, J., Fitzpatrick, C., Senciall, D., Stead, P., and Bailey, W.: An assessment of the physical oceanographic environment on the Newfoundland and Labrador Shelf during 2007, Canadian Science Advisory Secretariat Research Document, 2008/020, iv + 16 pp., Fisheries and Oceans Canada, Ottawa, Canada, 2008.

Colbourne, E., Craig, J., Bailey, W., Fitzpatrick, C., Senciall, D., and Stead, P.: An assessment of the physical oceanographic environment on the Newfoundland and Labrador Shelf during 2008, Canadian Science Advisory Secretariat Research Document, 2009/032, iv + 19 pp., Fisheries and Oceans Canada, Ottawa, Canada, 2009.

Colbourne, E., Craig, J., Fitzpatrick, C., Senciall, D., Stead, P., and Bailey, W.: An assessment of the physical oceanographic environment on the Newfoundland and Labrador Shelf during
2010, Canadian Science Advisory Secretariat Research Document, 2011/089, iv + 31 pp., Fisheries and Oceans Canada, Ottawa, Canada, 2011.

Colbourne, E., Craig, J., Fitzpatrick, C., Senciall, D., Stead, P., and Bailey, W.: An assessment of the physical oceanographic environment on the Newfoundland and Labrador Shelf during 2011, Canadian Science Advisory Secretariat Research Document, 2012/044, iv + 33 pp., Fisheries and Oceans Canada, Ottawa, Canada, 2012.

Colbourne, E., Craig, J., Fitzpatrick, C., Senciall, D., Stead, P., and Bailey, W.: An assessment of the physical oceanographic environment on the Newfoundland and Labrador Shelf during 2012, Canadian Science Advisory Secretariat Research Document, 2013/052, v + 35 pp., Fisheries and Oceans Canada, Ottawa, Canada, 2013.

Colbourne, E., Holden, J., Craig, J., Senciall, D., Bailey, W., Stead, P., and Fitzpatrick, C.: Physical Oceanographic Conditions on the Newfoundland and Labrador Shelf During 2013, Canadian Science Advisory Secretariat Research Document, 2014/094, v + 38 pp., Fisheries and Oceans Canada, Ottawa, Canada, 2014.

Colbourne, E., Holden, J., Craig, J., Senciall, D., Bailey, W., Stead, P., and Fitzpatrick, C.: Physical Oceanographic Conditions on the Newfoundland and Labrador Shelf During 2014, Canadian Science Advisory Secretariat Research Document, 2015/053, v + 37 pp., Fisheries and Oceans Canada, Ottawa, Canada, 2015.

Colbourne, E., Holden, J., Senciall, D., Bailey, W., Snook, S., and Higdon, J.: Physical Oceanographic Conditions on the Newfoundland and Labrador Shelf During 2015, Canadian Science Advisory Secretariat Research Document, 2016/079, v + 40 pp., Fisheries and Oceans Canada, Ottawa, Canada, 2016.

Colbourne, E., J. Holden, Snook, S., Han, G., Lewis, S., Senciall, D., Bailey, W., Higdon, J., and Chen, N.: Physical Oceanographic Conditions on the Newfoundland and Labrador Shelf during 2016, Canadian Science Advisory Secretariat Research Document, 2017/079, v + 50 pp., Fisheries and Oceans Canada, Ottawa, Canada, 2017.

Cyr, F. and Galbraith, P. S.: Newfoundland and Labrador climate index, Federated Research Data Repository, https://doi.org/10.20383/101.0301, 2020.

Cyr, F., Colbourne, E., Holden, J., Snook, S., Han, G., Chen, N., Bailey, W., Higdon, J., Lewis, S., Pye, B., and Senciall, D.: Physical Oceanographic Conditions on the Newfoundland and Labrador Shelf during 2017, Canadian Science Advisory Secretariat Research Document, 2019/051, iv + 58 pp., Fisheries and Oceans Canada, Ottawa, Canada, 2019.

Cyr, F., Colbourne, E., Galbraith, P. S., Gibb, O., Snook, S., Bishop, C., Chen, N., Han, G., and Senciall, D.: Physical Oceanographic Conditions on the Newfoundland and Labrador Shelf during 2018, Canadian Science Advisory Secretariat Research Document, 2020/018., iv + 48 pp., Fisheries and Oceans Canada, Ottawa, Canada, 2020.

de Young, B. and Rose, G. A.: On recruitment and distribution of Atlantic cod (Gadus morhua) off Newfoundland, Canadian Journal Fisheries Aquatic Sciences, 50, 2729-2741, 1993.

DFO: Short-term stock prospects for cod, crab and shrimp in the Newfoundland and Labrador region (Divisions 2J3KL), Canadian Science Advisory Secretariat Science Response, 2014/049, Fisheries and Oceans Canada, Ottawa, Canada, 2014. 
DFO: Oceanographic conditions in the Atlantic zone in 2019, Canadian Science Advisory Secretariat Science Advisory Report, 2020/028, Fisheries and Oceans Canada, Ottawa, Canada, 2020a.

DFO: 2019 Status of Northwest Atlantic Harp Seals, Pagophilus groenlandicus, Canadian Science Advisory Secretariat Science Advisory Report, 2020/020, Fisheries and Oceans Canada, Ottawa, Canada, 2020b.

Dickson, R. R., Meincke, J., Malmberg, S. A., and Lee, A.: The "great salinity anomaly" in the northern North Atlantic 19681982, Prog. Oceanogr., 1, 103-151, 1988.

Doubleday, W.: Manual on groundfish surveys in the Northwest Atlantic, NAFO Science Council Studies, Northwest Atlantic Fisheries Organization, Dartmouth, Canada, 2, 7-55, 1981.

Drinkwater, K. F.: Atmospheric and oceanic variability in the northwest Atlantic during the 1980s and early 1990s, Journal of Northwest Atlantic Fishery Science, 18, 77-97, https://doi.org/10.2960/J.v18.a6, 1996.

Florindo-López, C., Bacon, S., Aksenov, Y., Chafik, L., Colbourne, E., and Penny Holliday, N.: Arctic ocean and hudson bay freshwater exports: New estimates from seven decades of hydrographic surveys on the Labrador shelf, J. Climate, 33, 88498868, https://doi.org/10.1175/JCLI-D-19-0083.1, 2020.

Galbraith, P. S., Chassé, J., Shaw, J.-L., Dumas, J., Caverhill, C., Lefaivre, D., and Lafleur, C.: Physical Oceanographic Conditions in the Gulf of St. Lawrence during 2019, Canadian Science Advisory Secretariat Research Document, 2020/30, iv + 88 pp., Fisheries and Oceans Canada, Ottawa, Canada, 2020.

Galbraith, P. S., Larouche, P., and Caverhill, C.: A seasurface temperature homogenization blend for the Northwest Atlantic, Can. J. Remote Sens., in press, https://doi.org/10.1080/07038992.2021.1924645, 2021.

Hammill, M., Stenson, G. B., Mosnier, A., and Doniol-Valcroze, T.: Trends in harp seal, Pagophilus groenlandicus, abundance in the Northwest Atlantic, 1952-2019, Canadian Science Advirory Secretariat Research Document, 2020/006, iv + 28 pp., Fisheries and Oceans Canada, Ottawa, Canada, 2021.

Han, G., Colbourne, E., Pepin, P., and Xie, Y.: Statistical Projections of Ocean Climate Indices off Newfoundland and Labrador, Atmosphere-Ocean, 57, 3-17, https://doi.org/10.1080/07055900.2015.1047732, 2015.

Hebert, D., Pettipas, R., and Petrie, B.: Meteorological, sea ice and physical oceanographic conditions on the Scotian shelf and in the Gulf of Maine during 2009 and 2010, Canadian Science Advisory Secretariat Research Document, 2011/094, vi + 32 pp., Fisheries and Oceans Canada, Ottawa, Canada, 2011.

Hebert, D., Pettipas, R., and Brickman, D.: Physical Oceanographic Conditions on the Scotian Shelf and in the Gulf of Maine during 2018, Canadian Science Advisory Secretariat Research Document, pp. iv + 55 pp., Fisheries and Oceans Canada, Ottawa, Canada, 2020.

Holliday, N. P., Bersch, M., Berx, B., Chafik, L., Cunningham, S., Florindo-lópez, C., Hátún, H., Johns, W., Josey, S. A., Larsen, K. M. H., Mulet, S., Oltmanns, M., Reverdin, G., Rossby, T., Thierry, V., Valdimarsson, H., and Yashayaev, I.: Ocean circulation causes the largest freshening event for 120 years in eastern subpolar North Atlantic, Nat. Commun., 11, 585, https://doi.org/10.1038/s41467-020-14474-y, 2020.

Hutchings, J. A. and Myers, R. A.: What can be learned from the collapse of a renewable Resource? Atlantic cod, Gadus morhua, of Newfoundland and Labrador, Can. J. Fish. Aquat. Sci., 51, 2126-2146, https://doi.org/10.1139/f94-214, 1994.

ICNAF: List of ICNAF Standard Oceanographic Sections and Stations, ICNAF Selected Papers Number 3, 109-117, https://doi.org/10.1111/j.1949-8594.1914.tb16026.x, 1978.

International Ice Patrol: International Ice Patrol Annual Count of Icebergs South of 48 Degrees North, 1900 to Present, Version 1, NSIDC, https://doi.org/10.7265/z6e8-3027, 2020.

IPCC: IPCC Special Report on the Ocean and Cryosphere in a Changing Climate, edited by: Pörtner, H.-O., Roberts, D. C., Masson-Delmotte, V., Zhai, P., Tignor, M., Poloczanska, E., Mintenbeck, K., Alegría, A., Nicolai, M., Okem, A., Petzold, J., Rama, B., and Weyer, N. M., in press, 2019.

Koen-Alonso, M., Pepin, P., and Mowbray, F.: Exploring the role of environmental and anthropogenic drivers in the trajectories of core fish species of the Newfoundland-Labrador marine community, NAFO Scientific Council Meeting, SCR Doc. 1, 1-16, Northwest Atlantic Fisheries Organization, Dartmouth, Canada, 2010.

Koen-Alonso, M., Pepin, P., Fogarty, M. J., Kenny, A., and Kenchington, E.: The Northwest Atlantic Fisheries Organization Roadmap for the development and implementation of an Ecosystem Approach to Fisheries: structure, state of development, and challenges, Marine Policy, 100, 342-352, https://doi.org/10.1016/j.marpol.2018.11.025, 2019.

Lear, W. H. and Parsons, L. S.: History and management of the fishery for northern cod in NAFO Divisions $2 \mathrm{~J}, 3 \mathrm{~K}$ and $3 \mathrm{~L}$, in: Perspectives on Canadian marine fisheries management, edited by: Parsons, L. and Lear, W., Canadian Bulletin of Fisheries and Aquatic Sciences no. 226, Fisheries and Oceans Canada, Ottawa, Canada, 55-89, 1993.

Levin, P. S., Fogarty, M. J., Matlock, G. C., and Ernst, M.: Integrated ecosystem assessments. U.S. Department of Commerce, NOAA Tech. Memo. NMFS-NWFSC-92, 20 pp., National Oceanic and Atmospheric Administration, National Technical Information Service Springfield, VA, USA, 2008.

Marson, J. M., Myers, P. G., Hu, X., and Le Sommer, J.: Using Vertically Integrated Ocean Fields to Characterize Greenland Icebergs' Distribution and Lifetime, Geophys. Res. Lett., 45, 42084217, https://doi.org/10.1029/2018GL077676, 2018.

Martin, T. and Adcroft, A.: Parameterizing the fresh-water flux from land ice to ocean with interactive icebergs in a coupled climate model, Ocean Model., 34, 111-124, https://doi.org/10.1016/j.ocemod.2010.05.001, 2010.

McDougall, T. J. and Barker, P. M.: Getting started with TEOS-10 70 and the Gibbs Seawater (GSW) Oceanographic Toolbox, 28 pp., SCOR/IAPSO WG127, ISBN 978-0-646-55621-5, 2011.

Muffley, B., Gaichas, S., DePiper, G., Seagraves, R., and Lucey, S.: There Is no I in EAFM Adapting Integrated Ecosystem Assessment for Mid-Atlantic Fisheries Management, Coastal Manage., 49, 90-106, https://doi.org/10.1080/08920753.2021.1846156, 2021.

Mullowney, D. R., Rose, G. A., Dawe, E. G., Rowe, S., Maillet, G. L., and Pedersen, E. J.: Temperature influences on growth of unfished juvenile Northern cod (Gadus morhua) during stock collapse, Fish. Oceanogr., 28, 612-627, https://doi.org/10.1111/fog.12447, 2019.

Murphy, H., Adamack, A., and Cyr, F.: Identifying the drivers of the abrupt and persistent delay in capelin spawning timing following 
the 1991 stock collapse in Newfoundland, Canada, ICES Journal of Marine Science, in review, 2021.

NAFO: Report of the 10th Meeting of the NAFO Scientific Council Working Group on Ecosystem Science and Assessment (WGESA), Tech. Rep. NAFO SCS Doc. 17/21, Serial No. N6774, Northwest Atlantic Fisheries Organization, Dartmouth, Canada, 2017.

NAFO: Report of the 11th Meeting of the NAFO Scientific Council Working Group on Ecosystem Science and Assessment (WGESA), Tech. Rep. NAFO SCS Doc. 18/23, Serial No. N6900, Dartmouth, N.S., 2018.

Pepin, P., King, J., Holt, C., Gurney-Smith, H., Shackell, N., Hedges, K., and Bundy, A.: Incorporating climate, oceanographic and ecological change considerations into population assessments: A review of Fisheries and Oceans Canada's science advisory process, Canadian Science Advisory Secretariat Research Document, 2019/043 v + 76 p., Fisheries and Oceans Canada, Ottawa, Canada, 2019.

Petrie, B., Akenhead, S. A., Lazier, S. A., and Loder, J.: The cold intermediate layer on the Labrador and Northeast Newfoundland Shelves, 1978-86, NAFO Science Council Studies, 12, 57-69, 1988.

Petrie, B., Loder, J., Akenhead, S., and Lazier, J.: Temperature and salinity variability on the eastern Newfoundland shelf: The annual harmonic, Atmosphere-Ocean, 29, 14-36, https://doi.org/10.1080/07055900.1992.9649433, 1991.

Petrie, B., Loder, J., Lazier, J., and Akenhead, S.: Temperature and salinity variability on the eastern Newfoundland shelf: The residual field, Atmosphere-Ocean, 30, 120-139, https://doi.org/10.1080/07055900.1992.9649433, 1992.

Petrie, B., Pettipas, R. G., and Petrie, W. M.: An overview of meteorological, sea ice and sea surface temperature conditions off eastern Canada during 2005, Canadian Science Advisory Secretariat Research Document, 2006/039, iv + 38 pp., Fisheries and Oceans Canada, Ottawa, Canada, 2006a.

Petrie, B., Pettipas, R. G., Petrie, W. M., and Soukhovtsev, V. V.: Physical Oceanographic Conditions on the Scotian Shelf and in the Gulf of Maine during 2005, Canadian Science Advisory Secretariat Research Document, 2006/040, iv + 40 pp., Fisheries and Oceans Canada, Ottawa, Canada, 2006b.

Petrie, B., Pettipas, R. G., and Petrie, W. M.: An Overview of Meteorological, Sea Ice and Sea-Surface Temperature Conditions off Eastern Canada during 2006, Canadian Science Advisory Secretariat Research Document, 2007/022, iv + 38 pp., Fisheries and Oceans Canada, Ottawa, Canada, 2007a.

Petrie, B., Pettipas, R. G., Petrie, W. M., and Soukhovtsev, V. V.: Physical Oceanographic Conditions on the Scotian Shelf and in the Gulf of Maine during 2006, Canadian Science Advisory Secretariat Research Document, 2007/023, iv + 41 pp., Fisheries and Oceans Canada, Ottawa, Canada, 2007b.
Petrie, B., Pettipas, R. G., and Petrie, W. M.: An overview of meteorological, sea ice and sea surface temperature conditions off eastern Canada during 2007, Canadian Science Advisory Secretariat Research Document, 2008/016, iv + 38 pp., Fisheries and Oceans Canada, Ottawa, Canada, 2008a.

Petrie, B., Pettipas, R. G., Petrie, W. M., and Soukhovtsev, V. V.: Physical Oceanographic Conditions on the Scotian Shelf and in the Gulf of Maine during 2007, Canadian Science Advisory Secretariat Research Document, 2008/017, iv + 43 pp., Fisheries and Oceans Canada, Ottawa, Canada, 2008b.

Petrie, B., Pettipas, R. G., and Petrie, W. M.: An overview of meteorological, sea ice and sea surface temperature conditions off Nova Scotia and the Gulf of Maine during 2008, Canadian Science Advisory Secretariat Research Document, 2009/041, iv + 32 pp., Fisheries and Oceans Canada, Ottawa, Canada, 2009a.

Petrie, B., Pettipas, R. G., Petrie, W. M., and Soukhovtsev, V. V.: Physical Oceanographic Conditions on the Scotian Shelf and in the Gulf of Maine during 2008, Canadian Science Advisory Secretariat Research Document, 2009/039, iv + 13 pp., Fisheries and Oceans Canada, Ottawa, Canada, 2009b.

Stenson, G. B., Haug, T., and Hammill, M. O.: Harp Seals: Monitors of Change in Differing Ecosystems, Front. Marine Sci., 7, 569258, https://doi.org/10.3389/fmars.2020.569258, 2020.

Therriault, J., Petrie, B., Pepin, P., Gagnon, J., Gregory, D., Helbig, J., Herman, A., Lefaivre, D., Mitchell, M., Pelchat, B., Runge, J., and Sameoto, D.: Proposal for a northwest zonal monitoring program, Canadian Technical Report of Hydrographic and Ocean Sciences, 194, vii + 57 pp., Fisheries and Oceans Canada, Ottawa, Canada, 1998.

Vincent, L. A., Wang, X. L., Milewska, E. J., Wan, H., Yang, F., and Swail, V.: A second generation of homogenized Canadian monthly surface air temperature for climate trend analysis, J. Geophys. Res., 117, D18110, https://doi.org/10.1029/2012JD017859, 2012.

Vinther, B. M., Andersen, K. K., Jones, P. D., Briffa, K. R., and Cappelen, J.: Extending Greenland temperature records into the late eighteenth century, J. Geophys. Res., 111, D11105, https://doi.org/10.1029/2005JD006810, 2006.

World Meteorological Organization: WMO guidelines on the calculation of climate normals, Tech. rep., Geneva, Switzerland, 2017.

Yashayaev, I. and Loder, J. W.: Further intensification of deep convection in the Labrador Sea in 2016, Geophys. Res. Lett., 44, 1429-1438, https://doi.org/10.1002/2016GL071668, 2017. 